Document downloaded from:

http://hdl.handle.net/10251/70238

This paper must be cited as:

Martínez Molina, A.; Tort Ausina, I.; Cho, S.; Vivancos, J. (2016). Energy efficiency and thermal comfort in historic buildings: A review. Renewable and Sustainable Energy Reviews. 61:70-85. doi:10.1016/j.rser.2016.03.018.

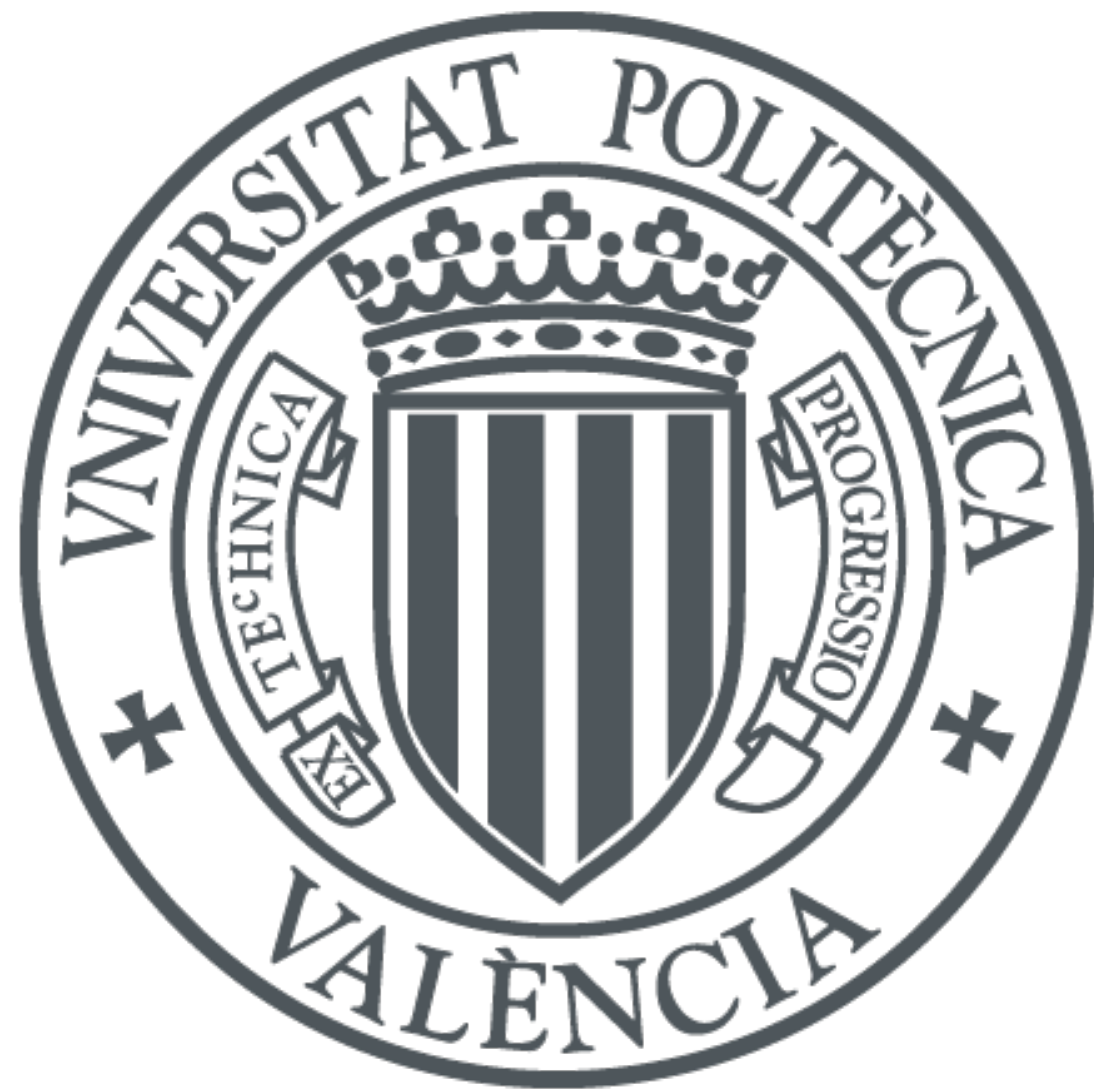

The final publication is available at

http://dx.doi.org/10.1016/j.rser.2016.03.018

Copyright Elsevier

Additional Information

NOTICE: this is the author's version of a work that was accepted for publication in <Renewable and Sustainable Energy Reviews>. Changes resulting from the publishing process, such as peer review, editing, corrections, structural formatting, and other quality control mechanisms may not be reflected in this document. Changes may have been made to this work since it was submitted for publication. A definitive version was subsequently published in Renewable and Sustainable Energy Reviews 


\title{
Energy Efficiency and Thermal Comfort in Historic Buildings: A review.
}

\author{
Antonio Martínez-Molinaa, Isabel Tort-Ausina b, Soolyeon Choc, José-Luis Vivancos,e,f,* \\ a Universitat Politècnica de València, Camino de Vera, s/n, 46022 Valencia, Spain \\ b Department of Applied Physics, Polytechnic University of Valencia, Camino de Vera, s/n, 46022 Valencia, Spain \\ c School of Architecture, North Carolina State University, Raleigh, NC, USA \\ d Instituto Interuniversitario de Investigación de Reconocimiento Molecular y Desarrollo Tecnológico (IDM), Unidad mixta \\ Universitat Politècnica de València-Universitat de València, Camino de Vera s/n, 46022 València, Spain \\ e CIBER de Bioingeniería, Biomateriales y Nanomedicina (CIBER-BBN), Spain \\ f Departamento de Proyectos de Ingeniería, Universitat Politècnica de València, Camino de Vera s/n, 46022 Valencia, Spain \\ 1. Introduction \\ 2. Research on Historic Buildings \\ 2.1. History of the Publication on Historic Buildings \\ 2.2. Interest in Historic Buildings Around the World \\ 2.3 Ages of the Historic Buildings Studied \\ 2.4 Research Purposes \\ 3. Type of Historic Buildings \\ 3.1. Residential Use \\ 3.2. Religious Use \\ 3.3. Academic and Palace Use \\ 3.4. Museum, Library and Theatre Use \\ 3.5. Urban areas \\ 3.6. Others \\ 4. Discussion \\ 5. Conclusion
}

\begin{abstract}
In recent years, energy efficiency and thermal comfort in historic buildings have become high-interest topics among scholars. Research has demonstrated that retrofitting buildings to current energy efficiency and thermal comfort standards is essential for improving sustainability and energy performance and for maintaining built heritage of historic structures. This study is an extensive overview of the literature surrounding this topic. This paper summarizes the different methods and techniques that have been used around the world to achieve performance refurbishments. Articles are organized based on the different building types used as case studies (residential, religious, academic and palace, museums, libraries and theatres, urban areas, and others). The results reveal that residential, religious and museum building types, especially from the last two centuries, have been most often used as case studies. Moreover, Europe, particularly Italy, is leading the research. The aim of this note is to demonstrate the feasibility of maintaining built heritage values of historic buildings while achieving significant improvements in their energy efficiency and thermal comfort.
\end{abstract}

Keywords: Energy-Efficiency, Thermal Comfort, Historic Buildings, Building Preservation, and Sustainability

\section{Introduction}

The world's global dependence on energy has been increasing at an alarming rate. According to the International Energy Agency (IEA), from 1971 to 2014, world-wide energy consumption increased by $92 \%$ [1]. The building sector has contributed to a large portion of this increase. In fact, in 2009, the United Nations Environment Program (UNEP) attributed more than 30\% of global greenhouse gas emissions and $40 \%$ of total energy consumption to the building sector [2]. The international community has taken definitive steps in an effort to curtail these global trends. The largest economies-the United States, the European Union, and China-have implemented measures that are particularly noteworthy.

The United States has adopted federal codes and standards to regulate energy consumption levels of new products, including appliances (appliance standards) and buildings (building energy codes). 
Appliance standards guide the energy use of heating, cooling and water heating equipment, major appliances, lamps and lighting systems, and other equipment. Individual states may also choose to regulate devices not covered by these standards. U.S. federal policy also requires energy performance labeling on appliances and other energy-using devices such as, the widely-adopted Energy Star label, which certifies high-performing machines. Building energy codes, on the other hand, regulate the overall performance of buildings and focus particularly on building envelopes. Building energy labeling schemes, such as the Home Energy Rating System (HERS) score, are now a required prerequisites for energy efficient mortgages and Energy Star Homes certifications.

The government of the United States has also been seeking to reduce energy consumption in commercial and residential structures by incentivizing consumers and prescribing policy goals. Tax incentives, including income, property and sales taxes, are offered at both state and federal levels. Moreover, in return for compensation, demand-side management (DSM) programs, supervised by state public utility commissions, encourage reductions in energy consumption by promoting voluntary decreases in demand. President Obama likewise began his presidency with aggressive goals aimed at curbing consumption. White House policy initiatives include a pledge to make commercial buildings $20 \%$ more efficient by 2020 and an executive order (Executive Order 13514), which, among other points, outlines the goal of having all new federal buildings achieve zero-net-energy by 2030 . The Obama Administration has also vowed to reduce energy use in new homes by $30-50 \%$ in comparison to 2009 levels of energy consumption; no target dates are specified for this objective [3].

The European Union developed two strategies to combat $\mathrm{CO}_{2}$ emissions and to promote energy efficiency in buildings. First, the Energy Performance Certification (EPC) was created in the early 1990's as an essential method for reducing energy use and $\mathrm{CO}_{2}$ emissions [4]. Later, in 2007, the European Union also adopted an Energy Policy Strategy called Horizon 20-20-20 ("H2020") as another initiative designed to reduce greenhouse gas emissions. Under this initiative, European countries agreed to reduce greenhouse gas and energy consumption by $20 \%$, to increase renewable energy sources by $20 \%$, and to increase energy efficiency in the building sector by $20 \%$ [5]. Member countries have been implementing various methods, laws, and projects in an attempt to achieve the goals prescribed by H2020; however, the overarching focus has been construction of efficient new buildings and refurbishing older ones [6]. Historic buildings have thus not been at the forefront of EPC and H2020 initiatives.

China's energy efficiency policies are largely defined and mandated at the federal level and thereafter implemented by provinces and municipalities. The policy system consists of laws and regulations on which major national plans and guidelines are based. The Eleventh Five-Year Plan (covering 2006-2010), for example, set a national goal of reducing energy intensity by $20 \%$ and encouraged considerable strengthening of energy efficiency policies. China has also made an effort to increase compliance with energy standards by regulating envelopes and HVAC systems in new buildings. Mandatory minimum standards for appliances have been adopted and an increase in regulation and enforcement of these standards is noticeable. Similar to the Energy Star labeling, China promotes a voluntary appliance energy efficiency labeling program and utilizes labeling conventions adopted from the EU. Corporate income tax incentives likewise promote the uptake of energy efficient technologies and measures [3]. Similar to the United States and the European Union, historic buildings escape the focus of China's energy efficiency policies and initiatives.

Energy efficiency is "a way of managing and restraining the growth in energy consumption"[7]. A building is therefore energy efficient "if it delivers more services for the same energy input, or the same services for less energy input"[7]. Due to the difficulty of implementing energy efficiency measures that do not compromise the architectural and other core values sought to be preserved, most building energy efficiency laws exclude historic buildings, places of worship, and other special purpose buildings of artistic and historic value [8]. Nevertheless, in recent years, some European countries have started to realize that they can no longer ignore built heritage values. The preservation of built heritage, however, poses a conflict between conservation on the one hand and contemporary procedures used to improve energy efficiency on the other. Moreover, individual perceptions of thermal comfort ("that condition of mind that expresses satisfaction with the thermal environment and is assessed by 
subjective evaluation") must be taken into account[9]. Balancing energy efficiency, obligatory architectural heritage conservation requirements, and users' thermal comforts is not an easy task.

The main goal of architectural refurbishment is to find this critical balance and to transmit restored buildings to future generations with the maximum preservation of heritage values. The authors argue that, as evidenced by the literature, the best way to perform this transmission is by adapting historic buildings to current consumption and thermal comfort requirements from lapsed into disuse. Doing so will not only extend the useful lives of buildings, but will also allow them to be admired by present and future generations alike. This paper serves as a comprehensive overview of energy efficiency in historic buildings research and summarizes findings spanning from 1978 to 2014. The results are presented in terms of increasing interests in historic buildings, energy efficiency, and thermal comfort. Historic buildings are categorized based on building uses.

\section{Research on Historic Buildings}

\subsection{History of the Publications on Historic Buildings}

Early studies and publications related to energy efficiency refurbishments of historic buildings began to emerge in the late 1970's and early 1980's [10-15]. Fig. 1 shows the number of research papers published from 1978 to 2014 in comparison to global Gross Domestic Product (GDP) levels. While Fig. 1 illustrates a general increase in publications over time, one visible and noteworthy correlation between GDP and research on energy efficiency in historic buildings is the decrease in publications during healthy economic times. The reverse is true as well; there have been definitive spikes in publications at times when GDP dipped, with the global financial crisis of 2007 serving as the most recent example. This association can likely be attributed to the fact that economic stagnation tends to result in increases in savings policies. The focus thereby shifts from new constructions to refurbishment and restoration projections and the implementation of efficiency measures.

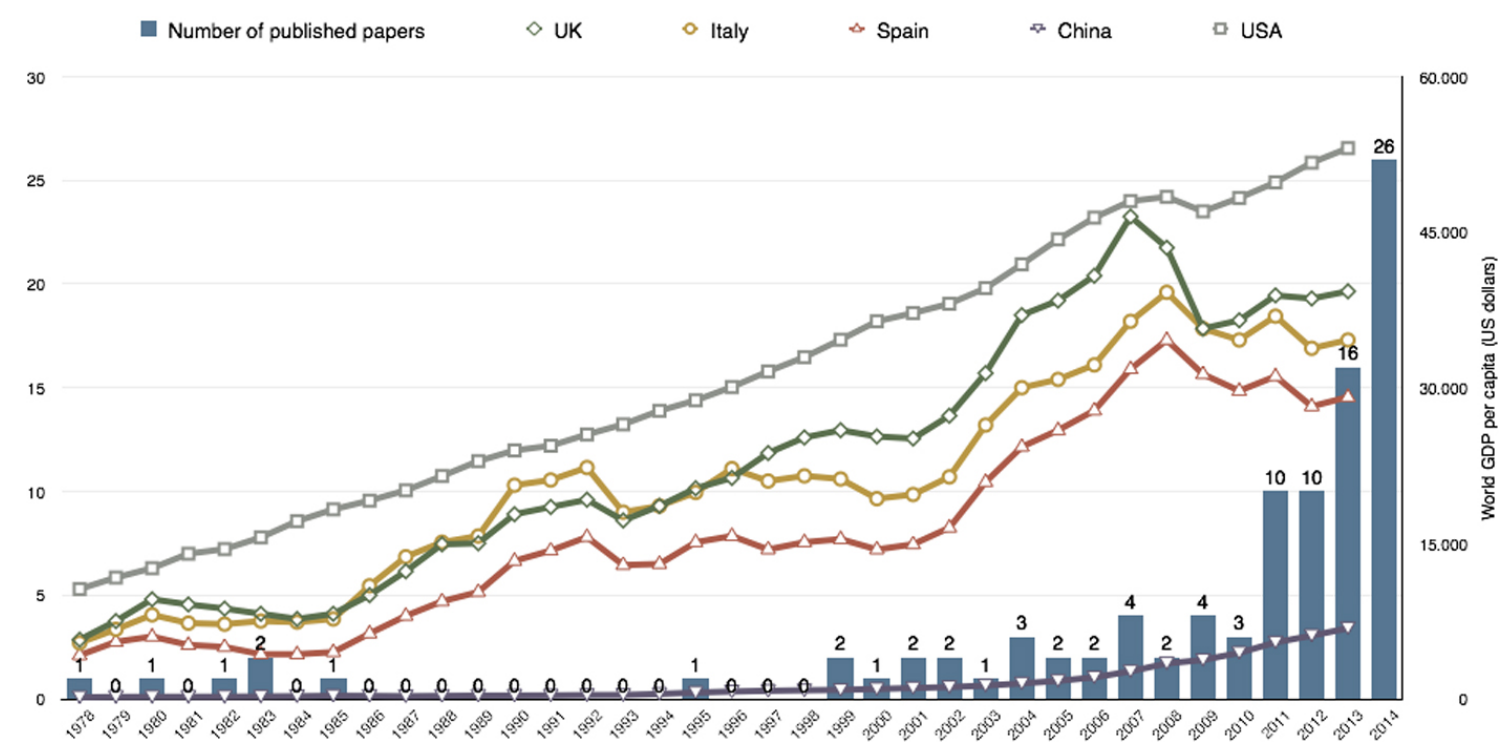

Fig.1. Number of Publications on Historic Building's Energy Efficiency and Thermal Comfort in the World, compared to the GDP per capita of the most important countries in this research.

The correlation between GDP levels and publication volumes, as exemplified by Fig. 1, can be traced back to the time research on energy efficiency refurbishments of historic buildings first appeared. For example, it has been noted that the two oil crises in 1973 and 1979, which created the necessity for starting to seek measures for improving energy efficiency of historic buildings, likely 
explain the sudden rise in research initiatives during the late the 70's and the early 80's. Research from this period largely focused on reducing energy consumption in buildings by improving insulation and building envelope performance. As a result, energy efficiency design technologies, such as passive design, the use of solar systems, and calculation and prediction methods of energy consumption, began to emerge as new research paths for historic buildings [11,13-15].

Thereafter, as the global economy improved and the focus shifted to construction and development, interest in the refurbishment of historic buildings saw a stagnation. There were just two papers published in the fifteen-year period between 1983 and 1998. Following the hiatus, research interests increased moderately from 1999 until 2010. Studies from this period began implementing monitoring techniques in order to analyze energy performance in historic buildings [16-18]. Technological advances, such as thermography $[19,20]$, allowed for a better understanding of building envelopes. Comparisons between historic and new building techniques $[19,21]$, indoor air condition analyses [22-24], and inhabitants' surveys were also introduced during that time [21,25].

From 2005 onward, some researchers have started projects focused in a new direction: artwork preservation [26-31]. Improving thermal comfort in historic buildings that hold artwork while, at the same time, respecting the heritage values of the buildings and keeping energy consumption within controlled ranges became a challenge for researchers between 2005 and 2010.

From 2011 to 2014, the volume of publications increased dramatically. Sustainable development relating to the rehabilitation of historic buildings was the theme of several studies from this time period. Research projects with economic perspectives, such as those that implemented life cycle tests [32-34] and economic viability analyses [34-38], also began to emerge. Between 2013 and the first half of 2014, research on energy efficiency in historic buildings diversified in terms of content and the types of buildings examined. For example, different methodologies were applied to study urban [39-43], rural [37,44-46], academic [47-49] and religious buildings [50-54], both individually and in urban areas [39-43]. Most of these studies focused on reusing heritage buildings and proposed suitable technical solutions for enhancing energy efficiency while maintaining building heritage values.

\subsection{Interest in Historic Buildings Around the World}

Research groups usually perform case studies of their own countries, where historic buildings are easily reachable. Sometimes, however, the strong built heritage of a country, like Italy, attracts scientists from abroad $[21,22,27,28,33,37,42,44,46,80,88,89,92-94]$. As illustrated in Fig 2, Italy is the country that has generated most of the energy efficiency in historic building research $[6,14,15,18,20,26,30,32,35,40,41,43,47,49-51,55-74]$. Italy is followed by the UK [21,25,75-82], Spain $[19,54,83-85]$ and China $[39,45,86]$. While there has been significant research done by international collaborators (represented by the "International" column in Fig. 2), those projects have often been led by British [46,87-89] and Italian [18,22,23,42,44,60,90] researchers. This distribution may be attributable to several factors, including a country's built heritage, the sheer availability of buildings, and scientific developments. For examples, Italy (followed by Spain and the UK) is one of the countries with the largest built heritage in the world $[65,66]$. Tourism has been and continues to be one of Italy's fastest growing and most profitable economic sectors, with an estimated industry revenue of $€ 136.1$ billion [91], which may explain the economic necessity for cultural preservation. Moreover, of the 5,367,000 monuments registered in Europe, over 4,000,000 are located in Italy. 


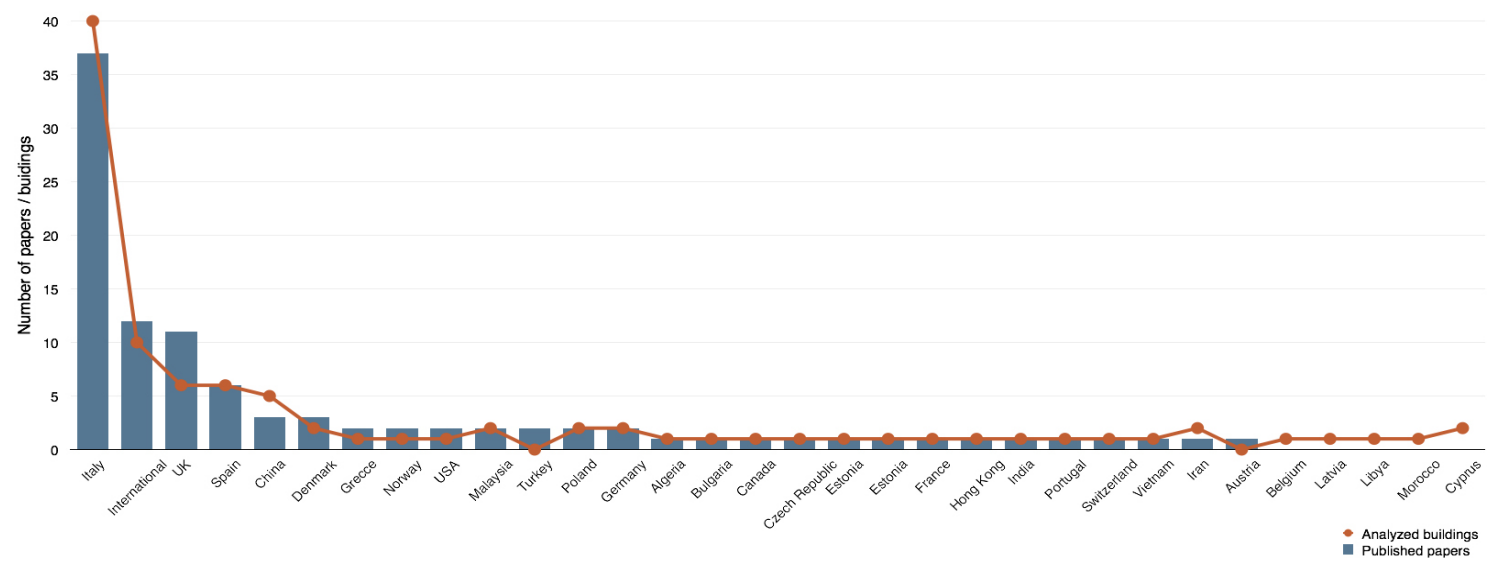

Fig. 2. Analyzed buildings and published papers per countries. Blue bars represent the number of papers published in each country and the orange line represents the number of historic buildings analyzed.

\subsection{Ages of the Historic Buildings Studied}

Likely due to the difficulty of finding buildings preserved well enough for research and analysis, very few buildings built before the 12th century have been analyzed for purposes of energy efficiency research. As shown in Fig. 3, most research that has been conducted thus far has been on 20th century constructions. The disproportional interest in 20th century buildings is partially attributable to less constricting preservation standards. Additionally, studying buildings from this period creates an immediate benefit. Since 20th century structures are often in use, efficiency and thermal comfort solutions are easy to implement and the buildings can therefore by quickly adapted to current needs.

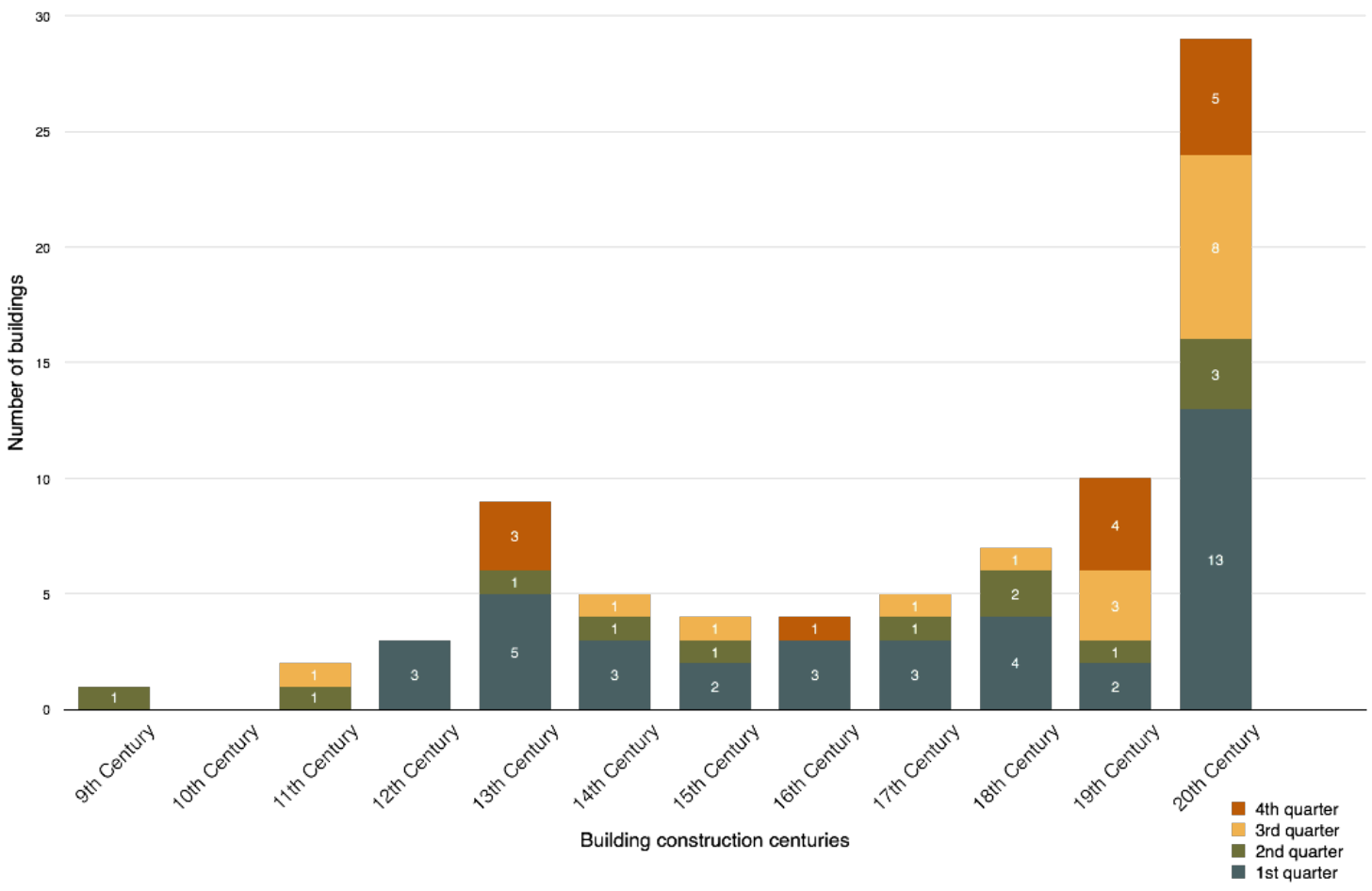

Fig. 3. Ages of the buildings analyzed. 


\subsection{Research Purposes}

Investigations of historic buildings can have various goals, as highlighted in Fig 4. The main research objective has been to improve the energy efficiency and thermal comfort in historic buildings, and $72 \%$ of the studies have been conducted for this purpose. Many historic buildings, including churches and museums, house artwork. Consequently, 16\% of investigations have aimed to conserve artwork and analyze internal conditions (temperature, humidity and air quality). The same analyses of indoor conditions, in addition to tests such as external wall performance analysis, have also been used in $4 \%$ of the studies. Finally, $8 \%$ of the studies have had multiple objectives, including the development of rehabilitation methodologies and theoretical and statistical examinations of the energy performance of cities and neighborhoods.

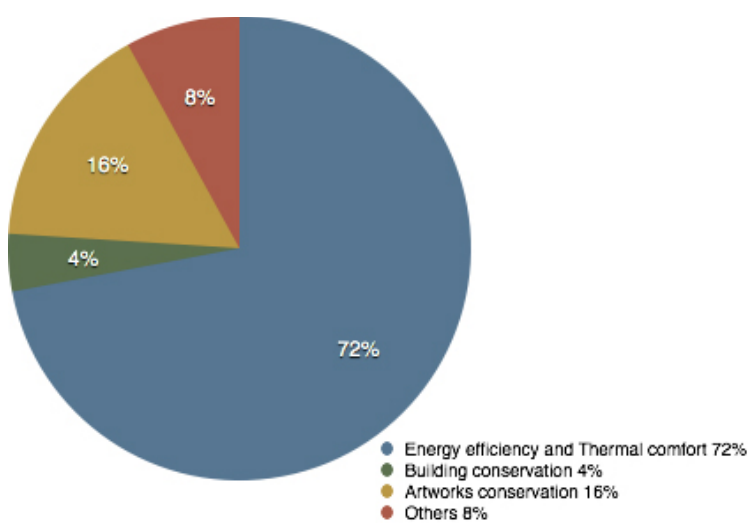

Fig. 4. Research purposes in analyzed papers.

\section{Types of Historic Buildings}

Most of the studies conducted can be classified by the type of historic building analyzed. As shown in Fig. 5, most researchers (23\%) analyzed residential buildings. Religious buildings (17\%), museums, theaters or libraries (11\%), academic and palaces $(17 \%)$, and studies on urban areas, such as neighborhoods, cities or even entire countries (10\%), were the focal points of most of the other studies. Finally, some investigations (23\%) cannot not be subsumed in any other category and include theoretical analyses that proposed new methodologies for applying energy efficiency measures.

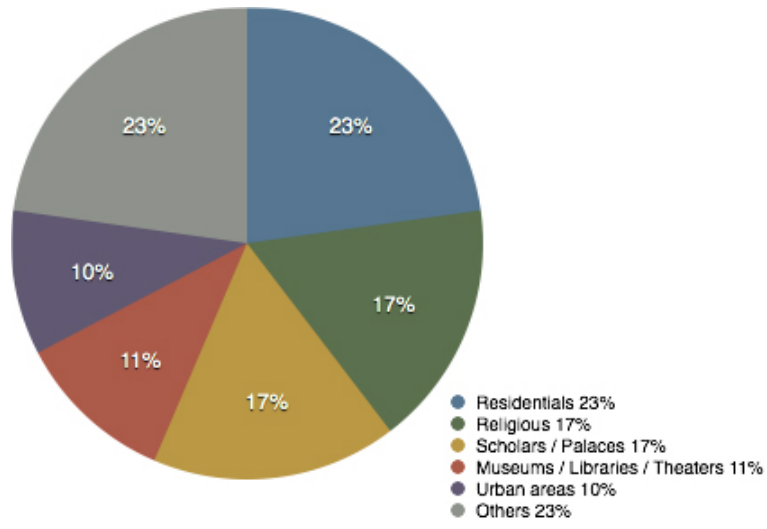

Fig. 5. Building uses. 


\subsection{Residential Use}

Historic residential buildings were the focal points of most of the investigations conducted on this topic. As depicted in Table 1, studies from the early 80's focused on strategies for changing building use and rehabilitating rural structures. For example, in 1982, Theis [12] published a paper applying innovative design strategies to a historic hotel to improve its energy efficiency and to convert it to a multi-purpose commercial facility. Theis [12] and Jankovich and Pucetti [14] proposed to change the building use of abandoned historic rural structures through restoration. The latter researchers discussed improvement strategies for rural buildings using wind, water and solar energy systems for power generation and passive solar systems for heating and cooling.

Table 1.

Residential buildings studies.

\begin{tabular}{|c|c|c|c|c|c|}
\hline $\begin{array}{c}\text { Year of } \\
\text { Publication }\end{array}$ & Researcher(s) & Origin of Researcher(s) & $\begin{array}{l}\text { Location of } \\
\text { Building }(\mathrm{s})\end{array}$ & $\begin{array}{c}\text { Year of } \\
\text { construction }\end{array}$ & $\begin{array}{l}\text { Analysis } \\
\text { techniques }\end{array}$ \\
\hline 2014 & Moran et al.[78] & UK & UK & 1810 & $\begin{array}{c}\text { Energy } \\
\text { refurbishment }\end{array}$ \\
\hline 2014 & Alev et al.[37] & $\begin{array}{c}\text { Sweden, Finland \& } \\
\text { Estonia }\end{array}$ & Sweden \& Finland & $1700-1940$ & Simulation \\
\hline 2014 & $\begin{array}{c}\text { Arumägi \& } \\
\text { Kalamees[38] }\end{array}$ & Estonia & Estonia & 1925 & Monitoring \\
\hline 2014 & Ben \& Steemers[75] & UK & UK & 1967 & Simulation \\
\hline 2014 & Fabbri et al.[65] & Italy & Italy & $\begin{array}{c}1959-70- \\
85-95\end{array}$ & Simulation \\
\hline 2014 & $\begin{array}{c}\text { Khalili \& } \\
\text { Amindeldar[96] }\end{array}$ & Iran & Iran & - & Monitoring \\
\hline 2014 & Polo \& Frontini[97] & Switzerland & Switzerland & $1600-1900$ & - \\
\hline 2013 & Li et al.[45] & China & China & 1300 & Surveys \\
\hline 2013 & Moschella et al.[40] & Italy & Italy & - & - \\
\hline 2013 & Pérez et al.[85] & Spain & Spain & 1800 & $\begin{array}{c}\text { Energy } \\
\text { refurbishment }\end{array}$ \\
\hline 2013 & Kacher[98] & Algeria & Algeria & 1600 & - \\
\hline 2013 & Stazi et al.[70] & Italy & Italy & $1945-74$ & Monitoring \\
\hline 2012 & Li et al.[86] & China & China & 1300 & Surveys \\
\hline 2012 & Morelli et al.[36] & Denmark & Denmark & 1896 & Simulation \\
\hline 2011 & Nguyen et al.[93] & Belgium \& Vietnam & Vietnam & 1900 & Monitoring \\
\hline 2011 & $\begin{array}{l}\text { Omar \& Syed- } \\
\text { Fadzil[99] }\end{array}$ & Malaysia & Malaysia & 1900 & Monitoring \\
\hline 2010 & Cantin et al.[95] & France & France & $1400-1900$ & Monitoring \\
\hline 2010 & Lucchi[67] & Italy & Italy & 1963 & Simulation \\
\hline 2004 & $\begin{array}{c}\text { Martín Ocaña et } \\
\text { al.[19] }\end{array}$ & Spain & Spain & $1890-1981$ & Thermography \\
\hline 2001 & Ealiwa et al.[21] & UK & Libya & - & Surveys \\
\hline 1996 & $\begin{array}{c}\text { Tassiopoulou et } \\
\text { al.[100] }\end{array}$ & Greece \& UK & Greece & 1750 & Simulation \\
\hline 1983 & $\begin{array}{l}\text { Jankovich \& } \\
\text { Puncetti[14] }\end{array}$ & - & Italy & - & - \\
\hline 1982 & Theis[12] & US & - & - & - \\
\hline
\end{tabular}

Almost two decades later, other investigations analyzing residential structures began to emerge, with most papers published on the topic between 2001 and 2013. Many of these papers drew comparisons between energy performances of historic and modern buildings. As a case in point, Ealiwa et al. [21] compared warm weather thermal sensations in traditional buildings (with natural ventilation) with modern buildings (with air conditioning). Inhabitants' surveys showed greater thermal comfort satisfaction in naturally-ventilated heritage buildings. Of the people surveyed, 39\% more reported feeling neither hot nor cold in traditional buildings as compared with air-conditioned modern buildings. Similarly, reports of hot sensations were $25 \%$ lower in traditional buildings. Indeed, according to Cantin et al. [95] (a field investigation made on eleven dwellings around France), some historic buildings perform better than new ones because ancient dwellings are interactive systems with bioclimatic properties more complex than modern dwellings with similar energy needs. The design and architectural elements of historic buildings therefore take into account climate, environmental and site 
conditions to maintain thermal comfort without mechanical systems. Another comparative study by Martín Ocaña et al. [19] demonstrated the utility of thermography in locating heat loss in different types of buildings, both modern and historic in Castillejo de Robledo, Spain. The field survey was carried out at sunrise and sunset in order to avoid solar radiation. The results showed that the technique used is especially beneficial for analyzing thermal inertia in traditional buildings and thermal losses in the modern ones. The most recent comparative investigations between modern and historic buildings were made by Li et al. [45,86]. These studies reaffirmed that historic buildings exhibit great performance in terms of energy efficiency and that the buildings analyzed consumed $28 \%$ less primary energy than modern buildings. Li et al.'s findings were confirmed by user surveys that showed a preference for thermal conditions within historic buildings.

While some researchers were interested in comparative analyses between modern and historic residential buildings, others focused their work on comprehensive projects and on improving energy efficiency in residential units in different climates. For example, Alev et al. [37], Arumägi and Kalamees [38] and Morelli et al. [36] researched historic buildings in cold climates, such as the Baltic Sea region. Investigations by Fabbri et al. [65] and Lucchi [67], Pérez et al. [85], and Omar and Syed-Fadzil [99] focused on warmer climates such as Italy, Spain, and Malaysia, respectively.

Alev et al. [37] calculated energy use for different renovation measures based on varying scenarios (focusing for instance first on installations and then on thermal comfort improvements) through validated simulation models. Results showed that improvements to building service systems and energy sources yield the most savings. Arumägi and Kalamees [38] analyzed the energy consumption and potential energy savings of historic wooden apartments in Estonia using field measurements, energy simulations and economic calculations. The refurbishment proposals, (based on different insulation measures), HVAC solutions and energy sources, achieved a primary energy consumption reductions between 20-65\%. Morelli et al. [36] implemented three types of retrofitting measures in an old Danish multi-family building in order to reach a "nearly-zero" energy building standard. Changing insulation materials, a windows retrofit and the installation of a decentralized mechanical ventilation system with heat recovery were the three procedures these researchers used. As a result, Morelli et al. [36] achieved a 68\% reduction in energy use and thereby fulfilled the legislative requirements for new Danish buildings.

As with cooler climates, warm conditions proved conducive to achieving high levels of energy savings. Khalili and Amildeldar [96], Kacher [98], and Nguyen et al. [93] demonstrated that warm environments are favorable to passive energy efficiency strategies. Through monitoring thermal indoor conditions, energy simulations, and CFD, these studies also confirmed that historic buildings exhibit great energy performance even when active comfort maintenance measures are not implemented.

Fabbri et al. [65] and Lucchi [67] also conducted their investigations in warmer climates. Fabbri et al. [65] created four energy retrofit simulations of a building in Italy. Each simulation calculated the building's energy performance based on the thermo-physical parameters that the building would have had had it been constructed during different points in time (specifically in either 1950, 1970, 1985 or 1995). The results showed that technological improvements in construction do not create energy savings; the relationship between technological improvement and energy savings is not therefore linear. Lucchi [67] created a cost-effective approach to energy conservation through technology, rather than sacrificing comfort and convenience. She performed an exhaustive energy audit of an Italian neighborhood using thermography, environmental monitoring, mechanical analysis, user's comfort analysis, and energy modeling. In conclusion, Lucchi [67] prepared a handbook to educate the inhabitants about the appropriate maintenance, management and use techniques for the buildings they occupied.

In addition, research conducted in the UK, which has an oceanic climate, has also been very revealing. Using the Passivehouse standard as a reference in a building refurbishment, Moran et al. [78] reduced $\mathrm{CO}_{2}$ emissions by $83 \%$ and increased energy savings by $55 \%$. Also in the UK, Ben and Steemers 
[75] found that occupant behavior education resulted in an overall increase in energy savings between $62 \%$ and $86 \%$. Based on their energy simulations study comparing an original and refurbished traditional dwelling in Athens and focusing on seasons rather than climates, Tassiopoulou et al. [100] concluded that it is necessary to evaluate thermal performance of historic buildings in both winter and summer seasons (especially when trying to restore a historic building for conservation and meeting the thermal requirements of current Building Regulations).

Focusing neither on comparative analyses nor on climactic factors, investigations by Polo and Frontini [97] and Moschella et al. [40] went a step further and resolved the problem of integrating solar thermal and photovoltaic panels with historic building frameworks.

Residential buildings were the subjects of $23 \%$ of the publications on energy efficiency and thermal comfort in historic buildings between 1982 and 2014. These studies primarily focused on buildings from the $20^{\text {th }}, 19^{\text {th }}$ and $14^{\text {th }}$ centuries, which were generally located in Italy, UK, Spain and China. The large interest in structures from these periods and geographic locations can be attributed to physical accessibility and the owners' interests in making the buildings more efficient. Energy simulation, building monitoring and, to a smaller degree, thermal satisfaction surveys, have been the most popular techniques used to analyze residential buildings.

\subsection{Religious Use}

Investigations centered on religious buildings have been prevalent, with 17 papers dedicated to this use. As delineated in Table 2, the two oldest studies, from 1995 and 2000, analyzed internal thermal comfort in places of worship in India and Bulgaria, respectively. In 1995, Tiwari et al. [16] showed that an ancient building in India (mahal) achieved thermal comfort on its own with the use of natural ventilation. Energy balance equations for various building components were used to analyze energy performance. Results showed that the original placement of windows allowed for thermal comfort in the rooms of the mahal, which was superior to the comfort that could have been achieved with the types of installations used in modern buildings. Bernardi et al. [90] focused on thermo-hygrometrical parameters, including the analysis of the porosity of the stone, in a church in Bulgaria prior to the restoration of frescoes on its internal walls. Bernardi et al. concluded that, while the microclimatic conditions of the church were stable, soluble salts must be decreased prior to restoration.

More recent studies have also contemplated thermal comfort and have monitored the inner temperatures and relative humidity levels. Loupa et al. [27] presented the results from two medieval churches in Cyprus and showed that the fluctuations in indoor temperatures, humidity levels, and levels of pollutants exceeded the recommended values. With the use of two networks of wireless sensors (one to measure the external weather conditions and the other for indoor temperature and humidity monitoring), Martínez-Garrido et al. [84] analyzed the differences in humidity levels along the walls and various heights of a church in Spain. The results showed that a longer thermal lag in particular wall areas contributed to indoor thermal comfort by releasing at night the heat absorbed during the day. Varas-Muriel et al. [54] designed and used a 3D sensor network to measure heat variances in a church in Talamanca de Jarama, Spain. The researchers concluded that traditional heating methods worked to accumulate heat in the upper levels of a church while retaining cold air at pew height. The rift between ideals and reality was discussed by Martins and Carlos [53], who showed the difficulty of maintaining temperature control and obtaining ideal levels of thermal performance in a convent in Lisbon. In order to assess energy performance, the investigators carried out an external walls analysis test with interior surface data loggers. Consequently, the examination revealed that during the summer months, the external walls worked well to reduce the heat flow into the building and the indoor temperature and humidity levels were thus stable. During the winter months, however, the walls alone could not have been relied on for thermal comfort. The researchers therefore established that additional actions, such as double-glazing the windows and improving heat gains on the south façade, should be taken to ensure the covenant's thermal comfort in the winter. 
Table 2.

Religious buildings' studies.

\begin{tabular}{|c|c|c|c|c|c|}
\hline $\begin{array}{c}\text { Year of } \\
\text { Publication }\end{array}$ & Researcher(s) & $\begin{array}{c}\text { Origin of } \\
\text { Researcher }(\mathrm{s})\end{array}$ & $\begin{array}{l}\text { Location of } \\
\text { Building(s) }\end{array}$ & $\begin{array}{c}\text { Year of } \\
\text { construction }\end{array}$ & $\begin{array}{c}\text { Analysis } \\
\text { techniques }\end{array}$ \\
\hline 2014 & Martins \& Carlos[53] & Portugal & Portugal & 1653 & Monitoring \\
\hline 2014 & $\begin{array}{c}\text { Woroniak \& Piotrowska- } \\
\text { Woroniak[52] }\end{array}$ & Poland & Poland & 1890-1902 & $\begin{array}{l}\text { Energy } \\
\text { refurbishment }\end{array}$ \\
\hline 2014 & Martínez-Garrido et al.[84] & Spain & Spain & 1200 & Monitoring \\
\hline 2014 & D’Agostino \& Congedo[63] & Italy & Italy & 1114 & CFD \\
\hline 2014 & Varas-Muriel et al.[54] & Spain & Spain & 1931 & Monitoring \\
\hline 2013 & Bernardi et al.[44] & Italy \& Spain & Italy & 1294 & Monitoring \\
\hline 2013 & D'Agostino et al.[51] & Italy & Italy & 1114 & CFD \\
\hline 2013 & $\begin{array}{l}\text { Maahsen-Milan \& } \\
\text { Fabbri[50] }\end{array}$ & Italy & Italy & 1600 & - \\
\hline 2010 & Camuffo et al.[60] & $\begin{array}{l}\text { Italy, Finland \& } \\
\text { Poland }\end{array}$ & Italy & $1350-1450$ & CFD \\
\hline 2009 & Balocco \& Grazzini[57] & Italy & Italy & 1500 & CFD \\
\hline 2008 & Balocco \& Calzolari[56] & Italy & Italy & 1232 & Simulation \\
\hline 2007 & Samek et al.[29] & Poland \& Belgium & Poland & 1736 & Monitoring \\
\hline 2007 & Bencs et al.[28] & $\begin{array}{l}\text { Belgium, Hungary } \\
\text { \& Netherlands }\end{array}$ & Italy & 1400 & Monitoring \\
\hline 2006 & Loupa et al.[27] & Greece & Cyprus & $850-1650$ & Monitoring \\
\hline 2005 & Cataldo et al.[72] & Italy & Italy & 1068 & Monitoring \\
\hline 2000 & Bernardi et al.[90] & Italy \& Bulgaria & Bulgaria & 1200 & Monitoring \\
\hline 1995 & Tiwari et al.[16] & India & India & 1050 & Monitoring \\
\hline
\end{tabular}

Shifting from thermal comfort assessments, heating systems in religious buildings have been of great interest to several researchers. One investigations, conducted by Woroniak \& PiotrowskaWoroniak [52], focused on how adding insulation and replacing old windows and doors can result in a reduction in energy demand and, consequently, consumption. This paper presented the environmental and the energy effects that can be achieved with the thermo-modernization of churches and by upgrading both the heating systems and the heat sources. In totality, the results suggested that energy refurbishment of the buildings as well as the modernization of the heat sources and the central heating systems is economically and environmentally justified. Maahsen-Milan and Fabbri et al. [50] examined the HVAC typologies in two refurbished buildings in Italy in order to propose a methodology for restoration and retrofitting projects focused on installations. Continuing with the HVAC systems research line, several papers analyzed different heating systems in churches $[28,29,60]$. Bencs et al. [28] studied the effects of a conventional hot-air heating as compared to a new system based on low temperature heating elements in the pews and carpets on the artworks in a church in Italy. The indoor air monitoring data revealed that the installation of the new heating system in the pews and carpet rendered the old system obsolete. Moreover, the new heating system transported a lower amount of pollutants and thereby reduced the chemical hazard to the works of art. Finally, the users' thermal comfort was improved because the heat and moisture was kept at and around the benches. Samek et al. [29] also monitored the indoor microclimate of a church (in Poland) to calculate the impact of a new heating system (overhead radiant heaters). The results showed that the new system allowed for a controlled delivery of heat to the particular areas where the people worshiped; the paintings were not negatively affected. Camuffo et al. [60] proposed a very similar strategy as the last two papers discussed and directed heat from radiators right to the pew area while leaving the indoor conditions of the church practically unaltered. This system was thereafter monitored for 3 years and the results showed that the pew-directed heating solution caused a significant betterment in thermal comfort and preservation of artwork. Moreover, the results of this study were included in three draft standards of the European Committee for Standardization created to control the environments of cultural heritage goods [60].

Also focusing on indoor climate controls, three papers presented results gathered with a Computational Fluid-Dynamics (CFDs) to show ventilation strategies for a crypt [51] and natural ventilation [57,63] in historic buildings. D'Agostino et al. [51] simulated the ventilation of the Crypt of Lecce Cathedral (Italy) using CFD tools. After the results of the model were confirmed by surveyed data, the researchers concluded that CFD calculations are very useful for predicting future indoor conditions. 
The investigators thereafter proposed that, to improve the Crypt's microclimate, users should refrain from opening all windows at the same time. In fact, ideally, to maintain the perfect conditions for the artworks, the windows should remain closed. Balocco and Grazzini [57] explored the velocity and air temperature distributions and the airflow patterns within a religious building in Italy. The scholars created a 3D model to use alongside the CFD tool to validate the results of the latter with the monitored data from the former. The researchers confirmed that ancient natural ventilation systems work well and create stable and comfortable internal microclimatic environments even in high temperatures and with solar radiation fluctuations. In their study, D'Agostino and Congedo [63] built on the methodology of the previous paper discussed and used 20 3D models together with CFD tools and five ventilation scenarios to analyze a church in Italy. The goal of this investigation was to find a solution that allowed for the creation of the optimal indoor microclimate for building preservation. The researchers were thus able to determine the optimal utilization scheme for the existing widows and door to achieve the desired interior conditions.

Different indoor conditions, such as natural lighting and air quality, were analyzed in investigations by Balocco and Calzolari [56] and Cataldo et al. [72], respectively. Balocco and Calzolari [56] ran a natural lighting design research in a medieval church in Florence, Italy. A solar radiation control, two light shelves, a skylight and two light pipes were installed in the building with no substantial modifications. Results showed that the installations ensured energy savings for cooling and lighting and as well as guaranteeing users' lighting comfort. Cataldo et al. [72] studied air quality in a building with deteriorating cultural heritage by integrating different non-destructive methods, such as microclimatic and ground penetrating radars. Together, the two papers pointed out the importance of integrating data about cultural heritage while making effectual decisions pertaining to heritage safeguards. Bernardi et al. [44] showed the efficacy of phase change materials when used as thermal energy storage units in heritage buildings. The study revealed, however, that direct contact between phase change materials and heritage objects is not recommended, as mechanical damage could result.

Overall, $17 \%$ of the published papers, up to and including the year 2014, analyzed energy efficiency and thermal comfort in religious buildings. Most of the religious constructions examined are located in Europe and more than half in Italy. The large interest in this building type can be attributed to the wide prevalence of these structures and easy access to them. Researchers, mainly Italian, Spanish, Polish and Greek, studied religious buildings from different periods ranging from the 9th to the 20th centuries; although, the most commonly-analyzed buildings were from 13th and 17th centuries. While the studies did focused much on energy rehabilitation projects, probably due to the complexity of implementing energy efficient measures, a new line of investigation had appeared and artwork preservation within religious building became a highly sought-after endeavor. To this end, monitoring techniques for indoor environmental pollutants, analyses of ventilation systems, and indoor CFD simulations were developed and used as a result of these studies.

\subsection{Academic and Palace use}

The palaces that have been analyzed are few and restricted to the following Italian locations: Benevento [101], Palermo [26], Florence [55,58] and Turin [62]. According to the present Italian energy legislation, historic buildings are excluded from energy refurbishment obligations (University, Agencies, Museums, etc.) [101] (Table 3).

Ascione et al. [101] had proposed a multi-criteria approach for the energy refurbishment of protected buildings and various retrofit actions had been verified and tested using simulation software to ascertain the energy performance effectiveness and economic feasibility of the building. The techniques were subsequently applied to a Palazzo dell'Aquila Bosco-Lucarelli in Southern Italy. It was thereafter determined that the energy refurbishment of this palace had the potential of providing a primary energy savings of around $22 \%$. The researchers pointed out, however, that the adoption of the proposed energy efficiency measures would only been justifiable if the interventions left the historic and cultural identity of the building untouched. Following the same research line, Costanzo et al. [26] monitored the indoor climatic conditions of a palace in Italy in order to correctly preserve the 
artwork it housed. The investigators thereby evaluated whether thermo-hygrometric values in the palace's interior met indoor comfort standards and concluded that it was necessary to install an airconditioning system and to run it continuously in summer and winter seasons.

Table 3.

Scholar and Palace buildings' studies.

\begin{tabular}{|c|c|c|c|c|c|}
\hline $\begin{array}{c}\text { Year of } \\
\text { Publication }\end{array}$ & Researcher(s) & $\begin{array}{c}\text { Origin of } \\
\text { Researcher }(\mathrm{s})\end{array}$ & $\begin{array}{l}\text { Location of } \\
\text { Building(s) }\end{array}$ & $\begin{array}{c}\text { Year of } \\
\text { construction }\end{array}$ & $\begin{array}{c}\text { Analysis } \\
\text { techniques }\end{array}$ \\
\hline 2014 & Buvik et al.[48] & Norway & Norway & 1914 & $\begin{array}{c}\text { Energy } \\
\text { refurbishment }\end{array}$ \\
\hline 2014 & Sauchelli et al.[47] & Italy & Italy & 1960 & Simulation \\
\hline 2014 & $\begin{array}{l}\text { Erhorn-Kluttig \& } \\
\text { Erhorn[102] }\end{array}$ & Germany & - & & $\begin{array}{c}\text { Energy } \\
\text { refurbishment }\end{array}$ \\
\hline 2014 & Zinzi et al.[74] & Italy & Italy & 1965 & $\begin{array}{l}\text { Monitoring \& } \\
\text { Energy } \\
\text { refurbishment }\end{array}$ \\
\hline 2014 & $\begin{array}{c}\text { Mørck \& } \\
\text { Paulsen[103] }\end{array}$ & Denmark & - & & $\begin{array}{c}\text { Energy } \\
\text { refurbishment } \\
\text { \& Simulation }\end{array}$ \\
\hline 2014 & Santoli et al.[49] & Italy & Italy & - & $\begin{array}{c}\text { Energy } \\
\text { refurbishment }\end{array}$ \\
\hline 2013 & $\begin{array}{l}\text { Corgnati \& } \\
\text { Perino[62] }\end{array}$ & Italy & Italy & 1718 & CFD \\
\hline 2011 & Ascione et al.[101] & Italy & Italy & 1520 & Monitoring \\
\hline 2011 & Lagüela et al.[104] & Spain & Spain & 1930 & Thermography \\
\hline 2010 & Boarin[105] & Italy & Italy & - & $\begin{array}{c}\text { Energy } \\
\text { refurbishment }\end{array}$ \\
\hline 2007 & Balocco[55] & Italy & Italy & 1299 & Simulation \\
\hline 2007 & $\begin{array}{c}\text { Balocco \& } \\
\text { Grazzini[58] }\end{array}$ & Italy & Italy & 1299 & CFD \\
\hline 2006 & Costanzo et al.[26] & Italy & Italy & 1300 & Monitoring \\
\hline 2004 & Camuffo et al.[73] & Italy & Italy & 1374 & Monitoring \\
\hline 2002 & Hanna[25] & UK & UK & 1900 & Monitoring \\
\hline 1985 & Butera et al.[15] & Italy & Italy & - & Simulation \\
\hline
\end{tabular}

Using a CFD software program (an advanced fluid-dynamic investigation tool) to run a transient conditions simulation, Balocco [55] created a 3D model that analyzed temperature and vapor concentration distributions, which have resulted from natural convection, fan coils systems and human presence. The goal of the study was to analyze a palace in Italy for a future refurbishment project. The building's structure was determined to have been conducive to the desirable indoor environmental conditions. Additionally, the control of thermal, hygrometric, and pollutant and thermal loads proved to add further benefit and guaranteed the appropriate environment for artwork conservation. Balocco and Grazzini [58] proposed a plant refurbishment in a palace in Italy by installing a mobile platform on the existing floor with a modular heating installation. CFD tools were used to simulate the energy performance of this solution and the results were also validated with experimental data. The refurbishment solution proved to be fully compatible with the palace and the microclimatic indoor conditions were also not significantly altered by the new installation. Corgnati and Perino [62] used CFD in order to optimize the ventilation strategy and the air distribution in a palace in Turin, Italy. CFD techniques were used in this study to assess and forecast the indoor microclimatic conditions and the simulations showed that the proposed HVAC refurbishments would render the palace suitable to host exhibitions.

Studies from the early 80's focused on strategies for rehabilitating school buildings. In their 1985 publication, Butera et al. [15] included energy conservation measures in the rehabilitation program of an ancient school buildings in Palermo (Italy). The research showed that, because of the building characteristics, occupation patterns and a mild climate, the most cost-effective refurbishment option was a properly-controlled heating system. Most of the studies pertaining to academic use, however, emerged between 2002 and 2014. These studies showed that energy simulation plays an essential role in analyzing the performance of retrofit measures. Since the effects of a single retrofitting measure cannot be isolated, many studies analyzed the combined effects of proposed intervention methods. For 
example, Sauchelli et al. [47] created a validated energy model that demonstrated a potential reductions in the heating demand (by 70\%) and heating power (by 33\%) in response to the implementation of passive solutions, such as new windows and thermal insulation.

The combination of metric information from a terrestrial laser scanner and thermal information from the thermographic camera has demonstrated the utility of thermography in locating heat loss in different types of buildings, both modern and historic. This method has not only given researchers a higher level of knowledge of the object examined, but has also allowed for quantification of the thermal studies if the clouds of points are texturized with thermographies. Lagüela et al. [104] utilized this approach and combined thermography with laser data to analyze a school in Vigo, Spain.

Research conducted on an existing high school building, in response to the European Directive 2010/31/UE (which promotes the construction of Nearly Zero-Energy Building expected from 2019), was also very revealing. In combination with active strategies and with the integration of photovoltaic panels, the overall energy need of the building was reduced to nearly zero. A potential energy demand reduction of $70 \%$ was also obtained with the passive solutions proposed. To test the different proposed scenarios and analyze the benefits in terms of energy consumption, dynamic energetic simulations were conducted using Trnsys 16 (Transient Simulation Tool) [47].

Santoli et al. [49] assessed public schools in Rome (Italy) in order to define possible intervention strategies for reducing energy consumption. This study proposed a complete evaluation of solutions useful for quantifying resources necessary to start the process of urban energy regeneration. Several standard interventions were defined according to the historic and architectural characteristics of the buildings. The analysis was performed using a simple Payback Time Analysis (PBT), which identified priorities for action by comparing the costs parameterized for standard retrofit interventions for the existing envelopes and systems with the benefits achievable through energy and cost-saving interventions. Hanna's [25] research evaluated and quantified daylight, acoustics and thermal comfort in the Glasgow School of Art and compared the actual measurements to the subjective perceptions of the patrons and visitors. Results showed that there is no relationship between levels of daylight (when daylight was raised above or lowered below the recommended standards) and the visual discomfort of occupants. Additionally, the users' surveys revealed that living in a historical building is a matter of great importance for almost all occupants. Following the same line of research, Boarin [105] demonstrated that operating effectively and in a scheduled way on existing school buildings (by adapting the physical environment and optimizing the use of resources) not only increases the quality of construction and occupants' comfort, but also improves the local entities' ability to manage economic resources.

Finally, "School of the Future" was an international project within the 7th Framework Program of the European Union. The core of this project was to realize the retrofit demonstration projects of four school buildings in four different European countries: (Germany [102], Italy [74], Denmark [103] and Norway [48]), which represent most of the climate conditions in Europe. The objective of this work was to develop an overview of the available building and system retrofit technologies for energy efficient school buildings, including the impact on the energy performance, indoor environment quality, and economic feasibility. Various measures were assessed, covering the following topics: reduction of heat losses from the building envelope; optimal handling of solar gains, heating, cooling, ventilation and lighting systems; and energy supply/generation systems.

Historic buildings dedicated to academic and palace use have had the lowest number of investigations dedicated to them. This is likely because, compared with other building types, academic buildings and palaces are restricted in the flexibility of their use and design and are therefore not as accessible as other structures. Most publications analyzed Italian structures (80\%), were led by Italian investigators $(67 \%)$, and examined buildings from the $13^{\text {th }}, 14^{\text {th }}$ and $20^{\text {th }}$ centuries. 


\subsection{Museum, Library and Theater use}

Table 4 below outlines studies from the early 80's that were focused on assessing the energy conservation possibilities in museums, libraries and theaters. Most of the studies analyzing museums for energy conservation purposes were published between 1999 and 2014; however, interest in the topic appeared as early as 1983.

Table 4.

\begin{tabular}{|c|c|c|c|c|c|}
\hline $\begin{array}{c}\text { Year of } \\
\text { Publication }\end{array}$ & Researcher(s) & $\begin{array}{c}\text { Origin of } \\
\text { Researcher(s) }\end{array}$ & $\begin{array}{l}\text { Location of } \\
\text { Building(s) }\end{array}$ & $\begin{array}{c}\text { Year of } \\
\text { construction }\end{array}$ & $\begin{array}{c}\text { Analysis } \\
\text { techniques }\end{array}$ \\
\hline 2014 & Fabbri \& Pretelli[64] & Italy & Italy & 1454 & Monitoring \\
\hline 2014 & Polo \& Frontini[97] & Switzerland & Switzerland & $1600-1900$ & - \\
\hline 2014 & Wang et al.[81] & UK & UK & 1855 & $\begin{array}{l}\text { Simulation \& } \\
\text { Energy } \\
\text { refurbishment }\end{array}$ \\
\hline 2012 & Farreny et al.[83] & Spain & Spain & - & - \\
\hline 2011 & $\begin{array}{l}\text { Maahsen-Milan \& } \\
\text { Simonetti[68] }\end{array}$ & Italy & Italy & $1700-1900$ & - \\
\hline 2009 & Corgnati et al.[30] & Italy & Italy & - & CFD \\
\hline 2004 & Gysels et al.[22] & $\begin{array}{c}\text { Belgium, Italy \& } \\
\text { Austria }\end{array}$ & Belgium & 1873 & Monitoring \\
\hline 2003 & Pavlogeorgatos[24] & Greece & - & - & - \\
\hline 2001 & Camuffo[23] & $\begin{array}{c}\text { Italy, Belgium, } \\
\text { Austria, UK \& New } \\
\text { Zealand }\end{array}$ & Europe & 1500 & Monitoring \\
\hline 1999 & Saïd et al.[17] & Canada & Canada & 1878 & $\begin{array}{l}\text { Monitoring \& } \\
\text { Thermography }\end{array}$ \\
\hline 1999 & Camuffo et al.[18] & Italy & Italy & 1582 & Monitoring \\
\hline 1983 & Ucar et al.[13] & - & - & - & - \\
\hline
\end{tabular}

In their publication, Ucar et al. [13] outlined the special environmental needs of museums and historic buildings that can be met through the methods that also conserve energy. The irreplaceable nature of museum collections and the historic structures that they often house mandates superior care and the elimination of any irreversible damage in the process of saving energy. Ucar et al. [13] summarized heating, cooling and humidity control guidelines that should be followed and recommended that all such buildings have an energy audit performed on their facilities. Later studies showed that humidity plays an essential role and can compromise the life of the building envelope and the artifacts within it $[17,24]$, as significant variations in humidity are not desirable for preservation. Saïd et al. [17] reached this conclusion by monitoring indoor environmental conditions in a museum in Ottawa, Canada. Similarly, Pavlogeorgatos [24] found that, together with humidity and pollution, temperature in exhibition rooms and storage areas is one of the most important factors causing artwork deterioration. He explained all the possible hazards for cultural goods that must to be controlled in a museum for the proper preservation of heritage items.

Due to the variety of the works of art housed in museums and the array of the materials that comprise them, microclimate control for cultural heritage must be given particular care. A methodology for microclimatic qualification assessment is described in Corgnati et al.'s [30] study, which is based on medium/long field monitoring of environmental parameters and a microclimatic quality evaluation expressed by the "Performance Indicator". Consequently, the researchers demonstrated that heating and air conditioning systems, when chiefly designed for human welfare, are not suitable for building conservation and can cause unfavorable temperature and humidity fluctuations [18,23]. Camuffo et al. [18] ran a summer and winter field investigation of the indoor microclimate of a museum in Venice, Italy, especially focusing on the influence of heating and cooling systems. It was determined that pollutants were more prevalent during the summer, as windows and doors are more frequently opened at that time. Camuffo et al. [23] likewise studied the microclimates, the air pollution levels, and the 
biological contaminations within four museums around Europe in order to propose improvement techniques.

Focusing more on the building exterior, Maahsen-Milan \& Simonetti [68] studied three cases of architectural and historic quality (Torino, Italy) and found a strategy for reducing energy costs and guaranteeing comfort and sustainability through various replacement interventions paid for by management bodies. (Due to high management costs, energy retrofitting was the choice for improving the building energy class.) The study also suggested improving performance of envelopes, installations and new enlargements in order to reach optimal energy efficiency and thermal comfort levels. Wang et al. [81], using both measured and modeling data, analyzed the hygrothermal environment in a national gallery. The simulations ran several cases to test a number of low energy solutions proposed in a gallery renovation project in order to reduce the energy consumption with no cost to the quality of environmental control. These options included three types of glazing for the skylights, two ways of insulating the timber roof structure, and adaptive environmental controls. Results showed that, a 28\% increase in energy savings could be reached by improving the glazing and another $20 \%$ increase in savings by adding roof insulations. The article concluded that a combination of all suggested solutions could have potentially resulted in a $60 \%$ energy consumption reduction. With the same objective of measuring and lowering energy consumption, Farreny et al. [83] analyzed the energy profile of 28 museums in Spain and found a correlation between water and energy consumption and the services the buildings provided. The relevant factors included building size, the rate of activity, and the number of visits and hours of operation.

Twelve articles, focused on libraries, museums and theaters, have been published and discussed in this section. Again, all of the buildings examined are located in Europe and most in Italy. Since these buildings often house artworks, books and documents that require special conditions for conservation, several studies have focused on analyzing indoor air quality. In addition to the variety of the in-house materials, the lack of homogeneous and consistent distribution of heat and vapor in space, which causes changes in air temperature and relative humidity. For these reasons, technical standards and regulations are essential for assessing the optimal values of the physical parameters in exhibition spaces [30]. An interesting approach to tackle this problem has been the development of maps of indoor microclimatic conditions (spatial distribution of relative humidity, temperature, air velocity, etc.) $[19,95]$ using modeling software.

\subsection{Urban areas}

As Table 5 shows, Italian neighborhoods were the topics of most of the research conducted on buildings in urban areas. Three of the studies focused on extensive refurbishment projects of the respective urban areas. First, Cardinale et al. [41] performed an experimental study of vernacular architecture in Southern Italy. External environmental climatic parameters were monitored (temperature, relative humidity and air velocity) for various periods of the yea, for an average duration between 12 and 15 days for each season. A simulation of the energy behaviors of the structures was then performed using the DesignBuilder/EnergyPlus software and the results thereafter validated by comparing the measured and simulated data and calculating the Inequality Coefficient. This analysis proved to be very effective for artistic and historic structures. The results indicated that, despite high thermal transmittance values of the walls, top-level indoor comfort could be reached using simple heating systems during the cold season.

De Berardinis et al. [42] pointed out the need for increasing the energy efficiency of heritage buildings in the Italian region of Abruzzo, which withstood considerable damage as a result of the 2009 earthquake. The destruction caused by this natural disaster led to a series of interventions including those aimed at improving energy efficiency. Researchers conducted on-site investigations to assess the feasibility of possible solutions. For example, thermal measurements, such as thermography testing and posterior thermo-flux-meter analysis, were taken. The data from these tests showed better thermal transmittance than expected from literature. A series of dynamic simulations were also performed using the DesignBuilder software. Finally, different solutions for improving energy efficiency were 
compared using a methodology based on a "case by case" approach that respected the peculiarities of each context. The research therefore showed that an earthquake could serve as an opportunity to propose building rehabilitation aimed at strengthening energy performance. Authors concluded that applying the proposed energy solutions for damaged masonry buildings could improve their energy performance by over $50 \%$.

The third study analyzing refurbishment projects was conducted by Bonomo and De Berardinis [43] who reported the implementation criteria for installing Photovoltaic (PV) solar panels in a historic settlement near L'Aquila, Italy, which were being refurbished after the 2009 earthquake. A simulation model with integrated PV was run and the settlement reached the Nearly-Zero Energy Settlement standard, thereby fulfilling the total energy demand using only solar energy. A field survey was also carried out on-site to monitor temperature and humidity using analysis techniques like thermography. Using the gathered data, the researchers compiled a list of interventions capable of achieving energy performance improvements of over 50\%. Similar to De Berardinis et al. [42], the earthquake in this investigation gave researchers an opportunity to renovate destroyed ancient structures while simultaneously increasing the efficiency of the buildings.

Tagliabue et al. [35] were less concerned with general refurbishment project and focused on redeveloping economically distressed areas by applying modern retrofitting to decayed buildings situated in historic locations. Specifically, this research analyzed methods by which Palazzolo Acreide, a UNESCO Heritage site in Sicily, Italy, can be converted into a "Spread Hotel". Tagliabue et al. [35] found that installing solar panels to power HVAC systems improved energy performance and was an effective way to preserve local heritage characteristics while renovating unused buildings. The results yielded an energy consumption reduction of $76 \%$ over 5 years.

Fabbri et al. [66] considered the problem of finding an evaluation and measurement tool for a town's energy consumption that takes into account the age and the characteristics of existing buildings. The study was performed in Ferrara (a city located in the northeaster part of Italy) and focused on a historic city center. A database of Energy Performance Certificates (EPC) was taken for the purpose of analyzing the energy class rating distribution for Ferrara city and its historic center. The Zone Energy Indicator (ZEI), which is a ratio between energy consumption and the sum of urban units, was found to be a useful tool for understanding the energy incidence of urban density and building typologies. A map project of EPC energy class was also performed with Geographical Information System (GIS).

Table 5.

Urban areas' studies.

\begin{tabular}{|c|c|c|c|c|c|}
\hline $\begin{array}{c}\text { Year of } \\
\text { Publication }\end{array}$ & Researcher(s) & $\begin{array}{c}\text { Origin of } \\
\text { Researcher(s) }\end{array}$ & $\begin{array}{l}\text { Location of } \\
\text { Building(s) }\end{array}$ & $\begin{array}{c}\text { Year of } \\
\text { construction }\end{array}$ & $\begin{array}{l}\text { Analysis } \\
\text { techniques }\end{array}$ \\
\hline 2014 & $\begin{array}{c}\text { Bonomo \& De } \\
\text { Berardinis [43] }\end{array}$ & Italy & Italy & $1200-1700$ & - \\
\hline 2014 & Tang et al.[46] & China \& UK & China & - & CFD \\
\hline 2014 & $\begin{array}{l}\text { De Berardinis et } \\
\text { al.[42] }\end{array}$ & Italy \& Canada & Italy & - & $\begin{array}{c}\text { Thermography, } \\
\text { Energy } \\
\text { refurbishment } \\
\text { \& Monitoring }\end{array}$ \\
\hline 2013 & Cardinale et al.[41] & Italy & Italy & 1200 & Monitoring \\
\hline 2013 & Wu \& Xu[39] & China & China & - & Simulation \\
\hline 2012 & Fabbri et al.[66] & Italy & Italy & - & - \\
\hline 2012 & Tang et al.[89] & $\begin{array}{l}\text { China, UK \& } \\
\text { Germany }\end{array}$ & China & - & CFD \\
\hline 2012 & Tagliabue et al.[35] & Italy & Italy & - & $\begin{array}{c}\text { Simulation \& } \\
\text { Energy } \\
\text { refurbishment }\end{array}$ \\
\hline 2012 & Moran et al.[79] & UK & UK & 1919 & - \\
\hline 2011 & Boeri et al.[59] & Italy & Italy & 1966 & $\begin{array}{c}\text { Surveys, } \\
\text { Simulation \& } \\
\text { Energy } \\
\text { refurbishment }\end{array}$ \\
\hline
\end{tabular}


Boeri et al.'s [59] research aimed at developing intervention strategies that could curb the feelings of disorientation and social dissatisfaction of Pilastros' residents-a high-density social housing settlement in Bologna, Italy. The investigation focused on identifying those factors that affect the selfimage of a large urban neighborhood. While the original hypothesis supposed that physical marginalization was the reason for low morale, the study results showed that dissatisfactions stemmed from factors such as deteriorating buildings that were either underutilized or used improperly.

Shifting the focus to Asia, Tang et al. [46] were concerned with sustainable design and planning of historic Chinese settlements. Following the interest that was initiated by a previous work [89], a simulation model was built using the thermal environment and wind patterns of a village in the centralwestern region of China. The study considered the usefulness of traditional bioclimatic design concepts and techniques and found that the construction style allowed for the creation of modern bioclimatic human environments. Wu \& Xu's [39] research aimed at predicting energy consumption and $\mathrm{CO}_{2}$ emissions of a world heritage area in China between the years 2010 and 2020. To address uncertainties and to optimize the parameters of the system, a fuzzy multiple objective programming model was used. The study results showed that energy consumption and $\mathrm{CO}_{2}$ emissions increased dramatically in response to rapid economic growth.

Back in Europe, Moran et al. [79] compared energy use data collected from 102 homes built before 1919 in Bath, UK-one of the only two complete cities with World Heritage status. The researchers were troubled by the lack of reliable data available to policy makers concerning the energy performance of historic buildings. The findings suggested that energy use in historic dwellings in Bath is lower than the national and regional averages. Moreover, Moran et al. [79] provided a statistically representative baseline that can now be used to assess district scale retrofits designed to reduce energy consumption and carbon emissions.

The articles about urban areas are very recent and were all published between 2011 and 2014 . Neighborhoods and towns that were investigated are primarily from the 20th, 18th and 13th centuries, and the Italian structures (followed by Chinese and British) have again been the most studied. Since these investigations were conducted on groups of buildings, the studies have had different objectives than the ones described in previous sections in this paper. Mainly, researchers concerned with this building use analyzed $\mathrm{CO}_{2}$ emissions, considered an economic point of view, the challenge of efficient urban planning, and the relationship between settlements and the environment they are in.

\subsection{Others}

Papers that cannot be grouped into any of the previously-described uses are discussed in this section (Table 6). One of the oldest studies found through this investigation dates to a 1978 publication by Prömmel [10]. Prömmel [10] presented basic concepts of thermal insulation and heating systems performance. Just two years later, Johnsen [11] published a paper reviewing experimental projects. These projects had applied energy-savings measures in existing buildings, reviewed methods for improving the building envelope, implemented building services systems and automatic controls, designed low energy consumption systems, and created experimental low energy buildings and methods for evaluating energy-saving techniques.

Prömmel and Johnsen were harbingers of energy efficiency and thermal comfort in historic buildings research. Their efforts were followed by publications focused on comparing the then-current energy expenditures of historic buildings to their future potential. For example, in Hong-Kong, Yung and Chan [34] reviewed literature about the factors that help achieve sustainable development in the preservation of historical buildings. The investigators made the claim that reusing historic buildings contributes to the overall decrease in carbon levels of a city. Subsequently, Troi [71] collected important data from buildings built before 1919 and between 1919 and 1945. Based on various statistics gathered from European reports and other investigations, Troi $[71]$ compared the actual energy efficiency performances of those buildings to the theoretical performances predicted by energy 
efficiency interventions. All results were statistically calculated and showed that interventions will reduce $\mathrm{CO}_{2}$ emissions by around $180 \mathrm{Mt}$ by 2050 and will thereby increase indoor thermal comfort and enhance the long-term conservation and sustainable management of our cities. Cardinale [32] compared an excavated building to a built vernacular construction in the Mediterranean by using current standards mandated by Italian legislation. The excavated building was found to have performed better than the regular one. Finally, Ozay's research[92] in northern Cyprus analyzed the responsive climatic behavior of traditional constructions throughout history. This study discussed societal and climatic influences on vernacular architecture and architecture from the Ottoman, British and modern periods.

Following the vernacular architecture research path, Hatamipour and Abedi [106] made an exhaustive collection of traditional passive construction techniques that cool buildings in hot and humid climates in Busherhr, Iran. The building techniques implemented, such as light colored buildings, wooden roofs and building shades, applied basic principles that can still be used today as passive cooling measures. Zhai and Previtali [107] conducted a study about the energy performances of vernacular buildings built in different environments utilizing various traditional construction techniques. These buildings were then compared against the rules established by the International Energy Conservation Code (IECC). The results showed that vernacular building techniques are still current and must be taken into account while designing modern buildings in order to optimize energy performance.

Godwin [76] conducted a comprehensive research and explained in detail the main factors to consider while trying to optimize the energy performance of a historic building. He also expounded some examples of refurbished energy efficient buildings with great heritage values. Ward and Choudhary [82] and Cardinale et al. [61] conducted other researches with similar purposes. Their studies were based on deep building analyses and precise energy retrofit projects. Ward and Choudhary [82] examined two buildings in The Royal Botanic Gardens in Kew, United Kingdom, while Cardinale et al. [61] studied two vernacular buildings in Matera and Alberobello, Italy. Ward and Choudhary [82] developed an energy retrofit methodology using simulation tools and discussed the potential for onsite generation and supply of energy. In addition to a less than 5-year payback for the installation, the analysis exhibited a $47 \%$ reduction in $\mathrm{CO}_{2}$ emissions and an energy consumption savings of over $40 \%$. Frequently, comprehensive investigations have focused on improving the building envelopes; however, there are also studies, such as the one conducted by Buhagiar et al. [87], which analyzed other building elements. Buhagiar et al. [87] measured the internal thermal mass, added an intermediate floor, scooped out the walls, added insulated indoor fabric and partitioning to optimize energy performance.

Insulating building envelopes has proved effective for achieving optimal energy levels. Zagorskas et al. [33] developed an exhaustive study of external walls based on thermal transmittance and humidity. Taking that analysis and some other data as a basis, this study analyzed energy performance of five external walls composed of five different insulation materials and thicknesses in order to reach the optimal solution. In fact, choosing the optimal insulation materials for historic building envelopes has been a topic of interest among other researchers. Sterflinger et al. [108] compared the biological susceptibility of organic insulation materials that were developed in a laboratory and installed in historic buildings. From a microbiological point of view, the research revealed that plaster and board made of perlite were the most suitable materials for thermal insulation. Furthermore, Grinzato et al. [20] ran an investigation on Infrared (IR) thermography to analyze the thermal properties of porous materials. In this study, specific thermal models were used to optimize the transient or quasi-stationary testing procedure using the Arsenal of Venice as a case study. IR thermography allowed the investigators to achieve a deeper knowledge of building conservation. The authors predicted that their technique would be utilized for future indoor microclimate analyses; this insight was accurate and the method has been used by other investigators.

Among the different methods of studying and analyzing thermal performance of historic buildings, user surveys (the collection of subjective indoor thermal comfort perceptions) have been popular 
among researchers. In this research line, studies, such as the one by Kamaruzzaman et al. [88] in Malaysia, used a thermal satisfaction survey to assess occupants' opinions pertaining to the Indoor Environmental Quality (IEQ) of six different buildings. The results showed that lighting satisfaction, for example, depends on parameters such as the building type and inhabitants' age, gender and occupation. Sibley and Sibley [80] conducted an investigational project on two commercial buildings used primarily as a public bathhouses, or Hammams. Sibley and Sibley [80] installed uniquely designed glass domes to replace the thick bulbs that covered the many orifices in the roofs of the Hammams. Additionally, solar panels were installed to power LED lights, which not only allowed the bathhouses to remain operational after sunset, but also curbed energy expenditure. As in Kamaruzzaman et al.'s [88] research, Sibley and Sibley's [80] determination of the effectiveness of the measures was based on the result of subjective surveys of lighting comfort; the measures improved the quality and quantity of daylight and allowed the Hammams to be used throughout the day. Focusing only on historic building installations, Pretelli et al. [69] developed a methodology for restoring the original fixings in heritage buildings. The aim of this study was not only to improve the energy efficiency of the systems, but also to keep the buildings in use and to preserve the installations as integral parts of the building's cultural value.

Table 6.

Other uses' studies.

\begin{tabular}{|c|c|c|c|c|c|}
\hline $\begin{array}{c}\text { Year of } \\
\text { Publication }\end{array}$ & Researcher(s) & $\begin{array}{c}\text { Origin of } \\
\text { Researcher(s) }\end{array}$ & $\begin{array}{l}\text { Location of } \\
\text { Building(s) }\end{array}$ & $\begin{array}{c}\text { Year of } \\
\text { construction }\end{array}$ & $\begin{array}{c}\text { Analysis } \\
\text { techniques }\end{array}$ \\
\hline 2014 & Johansson et al.[94] & Sweden \& Norway & - & 1900 & - \\
\hline 2014 & Zagorskas et al.[33] & Lithuania \& Latvia & Latvia & - & - \\
\hline 2014 & Ward \& Choudhary[82] & UK & UK & 1759 & $\begin{array}{c}\text { CFD, } \\
\text { Simulation \& } \\
\text { Energy } \\
\text { refurbishment }\end{array}$ \\
\hline 2013 & Cardinale et al.[32] & Italy & Italy & - & - \\
\hline 2013 & Fabbri[6] & Italy & Italy & - & - \\
\hline 2013 & Sterflinger et al.[108] & Austria & - & - & - \\
\hline 2013 & Sibley \& Sibley $[80]$ & UK & Morocco & - & - \\
\hline 2013 & Pretelli et al.[69] & Italy & Italy & - & - \\
\hline 2012 & $\begin{array}{c}\text { Lankester \& } \\
\text { Brimblecombe[77] }\end{array}$ & UK & Europe & - & - \\
\hline 2012 & Yung \& Chan[34] & Hong Kong & Hong Kong & - & - \\
\hline 2011 & Troi[71] & Italy & Europe & $1919-1945$ & $\begin{array}{c}\text { Energy } \\
\text { refurbishment }\end{array}$ \\
\hline 2011 & Godwin[76] & UK & UK & - & - \\
\hline 2011 & Buhagiar \& Jones[87] & Malta \& UK & - & - & - \\
\hline 2011 & Kamaruzzaman et al.[88] & Malaysia \& UK & Malaysia & 1900 & Surveys \\
\hline 2010 & Zhai \& Previtali[107] & USA & World & - & Simulation \\
\hline 2010 & Cardinale et al.[61] & Italy & Italy & 1204 & $\begin{array}{c}\text { Simulation, } \\
\text { Monitoring \& } \\
\text { Energy } \\
\text { refurbishment }\end{array}$ \\
\hline 2009 & Abuku et al.[109] & $\begin{array}{l}\text { Belgium \& } \\
\text { Denmark }\end{array}$ & Germany & - & $\begin{array}{c}\text { CFD \& } \\
\text { Simulation }\end{array}$ \\
\hline 2009 & Zítek \& Vyhlídal[31] & Czech Republic & $\begin{array}{c}\text { Czech } \\
\text { Republic }\end{array}$ & - & Monitoring \\
\hline 2008 & Hatamipour \& Abedi[106] & Iran & Iran & - & - \\
\hline 2005 & Ozay[92] & Turkey & Cyprus & - & - \\
\hline 2002 & Grinzato et al.[20] & Italy & Italy & 1104 & $\begin{array}{l}\text { Monitoring \& } \\
\text { Thermography }\end{array}$ \\
\hline 1980 & Johnsen[11] & Denmark & Denmark & - & - \\
\hline 1978 & Prömmel[10] & Germany & Germany & - & - \\
\hline
\end{tabular}

Artwork preservation has continued to be a topic of interest for researchers even when the buildings that housed the artworks were not necessarily museums, theaters, or libraries. Zítek and Vyhlídal [31] proposed new humidity control techniques based on the application of sorption phenomena models of a castle in Czech Republic. Rather than focusing on annual temperature variations, Zítek and Vyhlídal [31] stabilized the moisture content in artistic works and historic exhibits by adjusting the interior air humidity. Lankester and Brimblecombe [77] modeled future indoor 
environmental conditions in seven different historic rooms, including private rooms, holding artwork throughout Europe. This study used statistical regression to predict future climatic conditions in order to avoid paper degeneration and to create a standard for good practices. Johansson et al. [94] and Abuku et al. [109] focused on preservation of the building itself rather than the internal environment immediately surrounds the artworks. Johansson et al. [94] investigated the hygrothermal performance of a brick wall of a brewery with wooden beam-ends after its interior was insulated with vacuum insulation panels. By running numerical simulations, Abuku et al. [109] analyzed the impact of winddriven rain on the hygrothermal response, mold growth at interior wall surfaces, indoor climate and energy consumption.

The investigations discussed in this section are very diverse in terms of building typologies, methodologies, and general objectives. British researchers $(25 \%)$, followed by Italians (21\%), have taken the lead on this research. Nevertheless, most of the buildings analyzed are located on Italian (26\%), rather than UK $(11 \%)$ territory. The papers range from publications comparing the energy performance of vernacular and modern buildings to preservation of buildings and artworks. Although the goals of these studies were different from the ones described in the particular building uses, the techniques are nearly identical, and energy simulation and CFD, thermography and PV-panel integration were the most commonplace procedures.

\section{Discussion}

When the energy efficiency and thermal comfort in historic buildings discourse shifted from mere building and systems analysis to more complex aims, such as comparative exercises and artwork conservation, new investigative techniques and empirical objectives flooded the research arena. Today, the most common analytical procedures for analysis include thermography, energy simulations, thermal comfort surveys, and the monitoring of indoor environmental conditions. However, the past few years also saw an exponential growth in the application of CFD. CFD (Computational Fluid Dynamics) simulates indoor and outdoor fluid behaviors, making it extremely useful for natural and mechanical ventilation, heating and cooling examination. For example, CFD has allowed researchers to analyze passive ventilation patterns and airflows in historic structures and either apply them to modern designs or to determine the necessity for rehabilitation. Other new procedures that are noteworthy include: the use of GIS (Geographic Information System) for energy studies on an urban scale; EPC's (Energy Performance Certifications) for historic buildings, which allow for a uniform approach to keep the structures within modern energy efficiency standards; and, the use of PCM's (Phase Change Materials), which are smart materials that allow passive cooling or heating of historic structures while minimizing energy expenditure and the use of HVAC systems.

Interest in energy efficiency and thermal comfort in historic buildings research will continue to grow in the coming years. This is not only due to the need for conservation, but also due to the prevalence of historic building within our cities and neighborhoods. Historic buildings cannot therefore continue to be ignored by international standards of energy efficiency. In fact, ASHRAE recently published a draft of its new standard entitled, "Energy Guideline for Historical Buildings" [110]. The authors predict that techniques such as the implementation of Phase Change Materials (PCM), the use of Geographic Information Systems (GIS) (which allow for the visualization and analysis of any phenomenon that has a spatial component), Computational Fluid Dynamics (CFD) tools, and thermal comfort surveys will continue to be the primary tools for analysis.

\section{Conclusion}

In the last decade the importance of energy efficiency and thermal comfort in historic buildings has increased immensely, as evidenced by the many research projects and initiatives that have been undertaken The goal of merging energy efficiency measures and internal thermal comfort with the requisite of maintaining cultural and historic significance of the buildings motivates mechanical engineers, architects, historians, public institutions and private owners to work together. Meeting all professional requirements of every specialist involved, however, is extremely challenging. 
This paper has reviewed some of the key thermal comfort and energy efficiency studies in built heritage sites between 1978 and 2014. However, since the time this article was written, other noteworthy publications on the topic of energy efficiency in historic buildings emerged. Krarti [111] published a review outlining the energy sector characteristics in Kuwait. Tadeu et al.'s [112] study is an audit of environmental assessment and cost optimization for energy efficiency refurbishment for a 20th century building in Coimbra, Portugal (Classified as a UNESCO World Heritage site).

With goals similar to the ones shared by the authors of this paper, in 2012 and 2013,Yung [34] and Fabbri [6] respectively, also reviewed scientific literature pertaining to energy efficiency and thermal comfort in historic buildings. This paper, however, has aimed to take a step forward by widening the breadth of the research analyzed by Yung [34] and Fabbry [6]. The following conclusions are synthesized from this review:

- European countries are generally the ones most interested in improving indoor climate and reducing energy consumption in historic buildings. Italy, due to its huge built heritage, is leading this research.

- Buildings from the $19^{\text {th }}$ and the $20^{\text {th }}$ century are most frequently analyzed and used as study cases by researchers because of their accessibility, the ease with which energy retrofit strategies can be applied to these structures, and the generally lower protection levels.

- The main purpose of most of the investigations (73\%) was to reduce energy consumption and improve indoor thermal comfort while maintaining the buildings' historic value.

- Residential, religious and museums are the buildings types that are most frequently utilized with $24 \%, 17 \%$ and $14 \%$ of papers, respectively, dedicated to them.

Proper energy retrofits of heritage buildings undoubtedly contribute not only to reducing carbon emissions and energy consumption while enhancing sustainable development and improving indoor thermal comfort, but also to maintaining cultural and historic legacies. We should therefore aim to preserve built heritage for future generations. The best way to accomplish this goal by adapting historic structures to modern comfort and environmental standards and thereby keeping them in use. The strategies, projects, and ideas discussed in this paper provide useful examples for cities and governments worldwide.

\section{Acknowledgements}

This paper has been developed as a result of a mobility stay funded by the Erasmus Mundus Programme of the European Commission under the Transatlantic Partnership for Excellence in Engineering - TEE Project.

\section{References}

[1] International Energy Agency. Key World Energy Statistics. 2014.

[2] Buildings and climate change. Paris: 2009.

[3] Amecke H, Deason J, Hobbs A, Novikova A, Xiu Y, Shengyuan Z. Buildings Energy Efficiency in China, Germany, and the United States. Climate Policy Iniciative. San Francisco: 2013.

[4] Community E. Council Directive 93/76/EEC to limit carbon dioxide emissions by improving energy efficiency (SAVE). 1993.

[5] E u r o p e 202 0. Europe: 2010.

[6] Fabbri K. Energy incidence of historic building: Leaving no stone unturned. J Cult Herit 2013;14:e25-7. doi:10.1016/j.culher.2012.12.010.

[7] International Energy Agency. Http://www.iea.org 2015.

[8] Directive 2012/27/EU of the European Parliament and of the Council of 25 October 2012. 2012.

[9] Paliaga G, Schoen LJ, Alspach PF, Arens E a, Aynsley RM, Bean R, et al. Thermal Environmental Conditions for Human Occupancy. ASHRAE 2013;ASHRAE Sta:58. doi:ISSN 1041-2336. 
[10] Prömmel A. Increased energy efficiency in existing buildings. Habitat Int 1978;3:569-75. doi:10.1016/0197-3975(78)90020-6.

[11] Johnsen K. Energy conservation in the built enviroment. Build Environ 1980;15:203.

[12] Theis C. Saving energy in old buildings. Passiv Low Energy Altern 1982;I:51-8.

[13] Gail C. ENERGY CONSERVATION IN MUSEUMS AND HISTORIC BUILDINGS. ASHRAE J 1983;25 (8):32-7.

[14] Jankovich B, P. Puccetti. BUILDING REHABILITATION WITH RETROFIT OF PASSIVE AND LOW ENERGY SYSTEMS 1983:1983.

[15] Butera, F., D'Orso, A., Farruggia, S., Rizzo, G., Silvestrini G. ENERGY CONSERVATION IN 29 HISTORIC SCHOOL BUILDINGS IN PALERMO 1985.

[16] Tiwari GN, Lugani N, Singh AK, Garg HP. Performance studies of a passively cooled mahal. Energy Build 1995;22:91-9. doi:10.1016/0378-7788(94)00906-Z.

[17] Brown W. C, Shirtliffe C. J, Maurenbrecher AH. HP, Saïd MN. Monitoring of the building envelope of a heritage house: a case study. Energy Build 1999;30:211-9. doi:10.1016/S03787788(98)00031-0.

[18] Camuffo D, Brimblecombe P, Van Grieken R, Busse H-J, Sturaro G, Valentino A, et al. Indoor air quality at the Correr Museum, Venice, Italy. Sci Total Environ 1999;236:135-52. doi:10.1016/S0048-9697(99)00262-4.

[19] Martín Ocaña S, Cañas Guerrero I, González Requena I. Thermographic survey of two rural buildings in Spain. Energy Build 2004;36:515-23. doi:10.1016/j.enbuild.2003.12.012.

[20] Grinzato E, Bison PG, Marinetti S. Monitoring of ancient buildings by the thermal method. J Cult Herit 2002;3:21-9. doi:10.1016/S1296-2074(02)01159-7.

[21] Ealiwa M., Taki A., Howarth A., Seden M. An investigation into thermal comfort in the summer season of Ghadames, Libya. Build Environ 2001;36:231-7. doi:10.1016/S0360-1323(99)000712.

[22] Gysels K, Delalieux F, Deutsch F, Van Grieken R, Camuffo D, Bernardi A, et al. Indoor environment and conservation in the Royal Museum of Fine Arts, Antwerp, Belgium. J Cult Herit 2004;5:221-30. doi:10.1016/j.culher.2004.02.002.

[23] Camuffo D. Environmental monitoring in four European museums. Atmos Environ 2001;35:127-40. doi:10.1016/S1352-2310(01)00088-7.

[24] Pavlogeorgatos G. Environmental parameters in museums. Build Environ 2003;38:1457-62. doi:10.1016/S0360-1323(03)00113-6.

[25] Hanna R. Environmental appraisal of historic buildings in Scotland: the case study of the Glasgow School of Art. Build Environ 2002;37:1-10. doi:10.1016/S0360-1323(00)00099-8.

[26] Costanzo S, Cusumano A, Giaconia C, Giaconia G. Preservation of the artistic heritage within the seat of the Chancellorship of the University of Palermo. Build Environ 2006;41:1847-59. doi:10.1016/j.buildenv.2005.06.010.

[27] LOUPA G, CHARPANTIDOU E, KIOUTSIOUKIS I, RAPSOMANIKIS S. Indoor microclimate, ozone and nitrogen oxides in two medieval churches in Cyprus. Atmos Environ 2006;40:7457-66. doi:10.1016/j.atmosenv.2006.07.015.

[28] Bencs L, Spolnik Z, Limpens-Neilen D, Schellen HL, Jütte BAHG, Van Grieken R. Comparison of hot-air and low-radiant pew heating systems on the distribution and transport of gaseous air pollutants in the mountain church of Rocca Pietore from artwork conservation points of view. J Cult Herit 2007;8:264-71. doi:10.1016/j.culher.2007.05.001.

[29] Samek L, De Maeyer-Worobiec A, Spolnik Z, Bencs L, Kontozova V, Bratasz Ł, et al. The impact of electric overhead radiant heating on the indoor environment of historic churches. J Cult Herit 2007;8:361-9. doi:10.1016/j.culher.2007.03.006.

[30] Corgnati SP, Fabi V, Filippi M. A methodology for microclimatic quality evaluation in museums: Application to a temporary exhibit. Build Environ 2009;44:1253-60. doi:10.1016/j.buildenv.2008.09.012.

[31] Zítek P, Vyhlídal T. Model-based moisture sorption stabilization in historical buildings. Build Environ 2009;44:1181-7. doi:10.1016/j.buildenv.2008.08.014. 
[32] Cardinale T, Colapietro D, Cardinale N, Fatiguso F. Evaluation of the Efficacy of Traditional Recovery Interventions in Historical Buildings. A New Selection Methodology. Energy Procedia 2013;40:515-24. doi:10.1016/j.egypro.2013.08.059.

[33] Zagorskas J, Zavadskas EK, Turskis Z, Burinskienè M, Blumberga A, Blumberga D. Thermal insulation alternatives of historic brick buildings in Baltic Sea Region. Energy Build 2014;78:3542. doi:10.1016/j.enbuild.2014.04.010.

[34] Yung EHK, Chan EHW. Implementation challenges to the adaptive reuse of heritage buildings: Towards the goals of sustainable, low carbon cities. Habitat Int 2012;36:352-61. doi:10.1016/j.habitatint.2011.11.001.

[35] Tagliabue LC, Leonforte F, Compostella J. Renovation of an UNESCO Heritage Settlement in Southern Italy: ASHP and BIPV for a "Spread Hotel" Project. Energy Procedia 2012;30:1060-8. doi:10.1016/j.egypro.2012.11.119.

[36] Morelli M, Rønby L, Mikkelsen SE, Minzari MG, Kildemoes T, Tommerup HM. Energy retrofitting of a typical old Danish multi-family building to a "nearly-zero" energy building based on experiences from a test apartment. Energy Build 2012;54:395-406. doi:10.1016/j.enbuild.2012.07.046.

[37] Alev Ü, Eskola L, Arumägi E, Jokisalo J, Donarelli A, Siren K, et al. Renovation alternatives to improve energy performance of historic rural houses in the Baltic Sea region. Energy Build 2014;77:58-66. doi:10.1016/j.enbuild.2014.03.049.

[38] Arumägi E, Kalamees T. Analysis of energy economic renovation for historic wooden apartment buildings in cold climates. Appl Energy 2014;115:540-8. doi:10.1016/j.apenergy.2013.10.041.

[39] Wu Z, Xu J. Predicting and optimization of energy consumption using system dynamics-fuzzy multiple objective programming in world heritage areas. Energy 2013;49:19-31. doi:10.1016/j.energy.2012.10.030.

[40] Moschella A, Salemi A, A LF, Sanfilippo G, Detommaso M, Privitera A. Historic Buildings in Mediterranean Area and Solar Thermal Technologies: Architectural Integration vs Preservation Criteria. Energy Procedia 2013;42:416-25. doi:10.1016/j.egypro.2013.11.042.

[41] Cardinale N, Rospi G, Stefanizzi P. Energy and microclimatic performance of Mediterranean vernacular buildings: The Sassi district of Matera and the Trulli district of Alberobello. Build Environ 2013;59:590-8. doi:10.1016/j.buildenv.2012.10.006.

[42] De Berardinis P, Rotilio M, Marchionni C, Friedman A. Improving the energy-efficiency of historic masonry buildings. A case study: A minor centre in the Abruzzo region, Italy. Energy Build 2014;80:415-23. doi:10.1016/j.enbuild.2014.05.047.

[43] Bonomo P, De Berardinis P. PV Integration in Minor Historical Centers: Proposal of Guidecriteria in Post-earthquake Reconstruction Planning. Energy Procedia 2014;48:1549-58. doi:10.1016/j.egypro.2014.02.175.

[44] Bernardi A, Becherini F, Romero-Sanchez MD, Lopez-Buendia A, Vivarelli A, Pockelé L, et al. Evaluation of the effect of phase change materials technology on the thermal stability of Cultural Heritage objects. J Cult Herit 2013. doi:10.1016/j.culher.2013.11.002.

[45] Li Q, You R, Chen C, Yang X. A field investigation and comparative study of indoor environmental quality in heritage Chinese rural buildings with thick rammed earth wall. Energy Build 2013;62:286-93. doi:10.1016/j.enbuild.2013.02.057.

[46] Tang L, Nikolopoulou M, Zhang N. Bioclimatic design of historic villages in central-western regions of China. Energy Build 2014;70:271-8. doi:10.1016/j.enbuild.2013.11.067.

[47] Sauchelli M, Masera G, D’Antona G, Manzolini G. ISIS Facchinetti: A Nearly Zero Energy Retrofit in Italy. Energy Procedia 2014;48:1326-35. doi:10.1016/j.egypro.2014.02.150.

[48] Buvik K, Andersen G, Tangen S. Ambitious Renovation of a Historical School Building in Cold Climate. Energy Procedia 2014;48:1442-8. doi:10.1016/j.egypro.2014.02.163.

[49] de Santoli L, Fraticelli F, Fornari F, Calice C. Energy performance assessment and a retrofit strategies in public school buildings in Rome. Energy Build 2014;68:196-202. doi:10.1016/j.enbuild.2013.08.028.

[50] Maahsen-Milan A, Fabbri K. Energy restoration and retrofitting. Rethinking restoration projects by means of a reversibility/sustainability assessment. J Cult Herit 2013;14:e41-4. doi:10.1016/j.culher.2012.12.011. 
[51] D' Agostino D, Congedo PM, Cataldo R. Ventilation Control using Computational Fluid-dynamics (CFD) Modelling for Cultural Buildings Conservation. Procedia Chem 2013;8:83-91. doi:10.1016/j.proche.2013.03.012.

[52] Woroniak G, Piotrowska-Woroniak J. Effects of pollution reduction and energy consumption reduction in small churches in Drohiczyn community. Energy Build 2014;72:51-61. doi:10.1016/j.enbuild.2013.12.048.

[53] Martins AMT, Carlos JS. The retrofitting of the Bernardas' Convent in Lisbon. Energy Build 2014;68:396-402. doi:10.1016/j.enbuild.2013.07.087.

[54] Varas-Muriel MJ, Martínez-Garrido MI, Fort R. Monitoring the thermal-hygrometric conditions induced by traditional heating systems in a historic Spanish church (12th-16th C). Energy Build 2014;75:119-32. doi:10.1016/j.enbuild.2014.01.049.

[55] Balocco C. Daily natural heat convection in a historical hall. J Cult Herit 2007;8:370-6. doi:10.1016/j.culher.2007.04.004.

[56] Balocco C, Calzolari R. Natural light design for an ancient building: A case study. J Cult Herit 2008;9:172-8. doi:10.1016/j.culher.2007.07.007.

[57] Balocco C, Grazzini G. Numerical simulation of ancient natural ventilation systems of historical

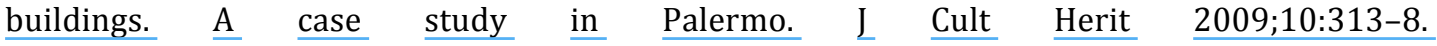
doi:10.1016/j.culher.2008.03.008.

[58] Balocco C, Grazzini G. Plant refurbishment in historical buildings turned into museum. Energy Build 2007;39:693-701. doi:10.1016/j.enbuild.2006.06.012.

[59] Boeri A, Antonini E, Longo D, Roversi R. The Redevelopment of The Heritage of Social Housing in Italy: Survey and Assessment Instruments. The Case Study of Pilastro Neighborhood in Bologna. Procedia Eng 2011;21:997-1005. doi:10.1016/j.proeng.2011.11.2105.

[60] Camuffo D, Pagan E, Rissanen S, Bratasz Ł, Kozłowski R, Camuffo M, et al. An advanced church heating system favourable to artworks: A contribution to European standardisation. J Cult Herit 2010;11:205-19. doi:10.1016/j.culher.2009.02.008.

[61] Cardinale N, Rospi G, Stazi A. Energy and microclimatic performance of restored hypogeous buildings in south Italy: The "Sassi" district of Matera. Build Environ 2010;45:94-106. doi:10.1016/j.buildenv.2009.05.017.

[62] Corgnati SP, Perino M. CFD application to optimise the ventilation strategy of Senate Room at Palazzo Madama in Turin (Italy). J Cult Herit 2013;14:62-9. doi:10.1016/j.culher.2012.02.007.

[63] D'Agostino D, Congedo PM. CFD modeling and moisture dynamics implications of ventilation scenarios in historical buildings. Build Environ 2014. doi:10.1016/j.buildenv.2014.05.007.

[64] Fabbri K, Pretelli M. Heritage buildings and historic microclimate without HVAC technology: Malatestiana Library in Cesena, Italy, UNESCO Memory of the World. Energy Build 2014;76:1531. doi:10.1016/j.enbuild.2014.02.051.

[65] Fabbri K, Tronchin L, Tarabusi V. Energy Retrofit and Economic Evaluation Priorities Applied at an Italian Case Study. Energy Procedia 2014;45:379-84. doi:10.1016/j.egypro.2014.01.041.

[66] Fabbri K, Zuppiroli M, Ambrogio K. Heritage buildings and energy performance: Mapping with GIS tools. Energy Build 2012;48:137-45. doi:10.1016/j.enbuild.2012.01.018.

[67] Lucchi E. PRESERVATION OF HERITAGE, ENVIRONMENTAL QUALITY AND ENERGY EFFICIENCY : 2010:8.

[68] Maahsen-Milan A, Simonetti M. Auditoria and Public Halls. The preserved Architectonic Heritage, in the Perspective of Sustainability. Procedia Eng 2011;21:711-20. doi:10.1016/j.proeng.2011.11.2069.

[69] Pretelli M, Ugolini A, Fabbri K. "Historic plants as monuments" preserving, rethinking and reusing historic plants. J Cult Herit 2013;14:S38-43. doi:10.1016/j.culher.2012.12.013.

[70] Stazi F, Vegliò A, Di Perna C, Munafò P. Experimental comparison between 3 different traditional wall constructions and dynamic simulations to identify optimal thermal insulation strategies. Energy Build 2013;60:429-41. doi:10.1016/j.enbuild.2013.01.032.

[71] Troi A. Historic buildings and city centres - the potential impact of conservation compatible energy refurbishment on climate protection and living conditions. Energy Manag Cult Herit 2011. 
[72] Cataldo R, De Donno A, De Nunzio G, Leucci G, Nuzzo L, Siviero S. Integrated methods for analysis of deterioration of cultural heritage: The Crypt of "Cattedrale di Otranto." J Cult Herit 2005;6:29-38. doi:10.1016/j.culher.2004.05.004.

[73] Camuffo D, Pagan E, Bernardi A, Becherini F. The impact of heating, lighting and people in reusing historical buildings: a case study. J Cult Herit 2004;5:409-16. doi:10.1016/j.culher.2004.01.005.

[74] Zinzi M, Agnoli S, Battistini G, Bernabini G. Retrofit of an Existing School in Italy with High Energy Standards. Energy Procedia 2014;48:1529-38. doi:10.1016/j.egypro.2014.02.173.

[75] Ben H, Steemers K. Energy retrofit and occupant behaviour in protected housing: A case study of the Brunswick Centre in London. Energy Build 2014. doi:10.1016/j.enbuild.2014.05.019.

[76] Godwin PJ. Building Conservation and Sustainability in the United Kingdom. Procedia Eng 2011;20:12-21. doi:10.1016/j.proeng.2011.11.135.

[77] Lankester P, Brimblecombe P. Future thermohygrometric climate within historic houses. J Cult Herit 2012;13:1-6. doi:10.1016/j.culher.2011.06.001.

[78] Moran F, Blight T, Natarajan S, Shea A. The use of Passive House Planning Package to reduce energy use and CO2 emissions in historic dwellings. Energy Build 2014;75:216-27. doi:10.1016/j.enbuild.2013.12.043.

[79] Moran F, Natarajan S, Nikolopoulou M. Developing a database of energy use for historic dwellings in Bath, UK. Energy Build 2012;55:218-26. doi:10.1016/j.enbuild.2012.09.016.

[80] Sibley M, Sibley M. Hybrid Green Technologies for Retrofitting Heritage Buildings in North African Medinas: Combining Vernacular and High-tech Solutions for an Innovative Solar Powered Lighting System for Hammam Buildings. Energy Procedia 2013;42:718-25. doi:10.1016/j.egypro.2013.11.074.

[81] Wang F, Pichetwattana K, Hendry R, Galbraith R. Thermal performance of a gallery and refurbishment solutions. Energy Build 2014;71:38-52. doi:10.1016/j.enbuild.2013.11.059.

[82] Ward RM, Choudhary R. A bottom-up energy analysis across a diverse urban building portfolio: retrofits for the buildings at the Royal Botanic Gardens, Kew, UK. Build Environ 2014;74:13248. doi:10.1016/j.buildenv.2013.12.018.

[83] Farreny R, Oliver-Solà J, Escuder-Bonilla S, Roca-Martí M, Sevigné E, Gabarrell X, et al. The metabolism of cultural services. Energy and water flows in museums. Energy Build 2012;47:98106. doi:10.1016/j.enbuild.2011.11.050.

[84] Martínez-Garrido MI, Aparicio S, Fort R, Anaya JJ, Izquierdo MAG. Effect of solar radiation and humidity on the inner core of walls in historic buildings. Constr Build Mater 2014;51:383-94. doi:10.1016/j.conbuildmat.2013.10.068.

[85] Pérez Gálvez F, Rubio de Hita P, Ordóñez Martín M, Morales Conde MJ, Rodríguez Liñán C. Sustainable restoration of traditional building systems in the historical centre of Sevilla (Spain). Energy Build 2013;62:648-59. doi:10.1016/j.enbuild.2012.05.009.

[86] Li Q, Sun X, Chen C, Yang X. Characterizing the household energy consumption in heritage Nanjing Tulou buildings, China: A comparative field survey study. Energy Build 2012;49:31726. doi:10.1016/j.enbuild.2012.02.023.

[87] Buhagiar, P. Jones V. Refurbishment of historic buildings: Thermal mass modified, its influence on indoor comfort, energy efficiency and heritage value (2011). 27th Int. Conf. Passiv. Low Energy Archit. Archit. Sustain. Dev., 2011, p. 2011.

[88] Kamaruzzaman SN, Egbu CO, Zawawi EMA, Ali AS, Che-Ani AI. The effect of indoor environmental quality on occupants' perception of performance: A case study of refurbished historic buildings in Malaysia. Energy Build 2011;43:407-13. doi:10.1016/j.enbuild.2010.10.003.

[89] Tang L, Nikolopoulou M, Zhao F, Zhang N. CFD modeling of the built environment in Chinese historic settlements. Energy Build 2012;55:601-6. doi:10.1016/j.enbuild.2012.09.025.

[90] Bernardi A, Todorov V, Hiristova J. Microclimatic analysis in St. Stephan's church, Nessebar, Bulgaria after interventions for the conservation of frescoes. J Cult Herit 2000;1:281-6. doi:10.1016/S1296-2074(00)01084-0.

[91] Invitalia. Investment Opportunities. Rome: 2012. 
[92] Ozay N. A comparative study of climatically responsive house design at various periods of Northern Cyprus architecture. Build Environ 2005;40:841-52. doi:10.1016/j.buildenv.2004.08.024.

[93] Nguyen A-T, Tran Q-B, Tran D-Q, Reiter S. An investigation on climate responsive design strategies of vernacular housing in Vietnam. Build Environ 2011;46:2088-106. doi:10.1016/j.buildenv.2011.04.019.

[94] Johansson P, Geving S, Hagentoft C-E, Jelle BP, Rognvik E, Kalagasidis AS, et al. Interior insulation retrofit of a historical brick wall using vacuum insulation panels: Hygrothermal numerical simulations and laboratory investigations. Build Environ 2014;79:31-45. doi:10.1016/j.buildenv.2014.04.014.

[95] Cantin R, Burgholzer J, Guarracino G, Moujalled B, Tamelikecht S, Royet BG. Field assessment of thermal behaviour of historical dwellings in France. Build Environ 2010;45:473-84. doi:10.1016/j.buildenv.2009.07.010.

[96] Khalili M, Amindeldar S. Traditional solutions in low energy buildings of hot-arid regions of Iran. Sustain Cities Soc 2014. doi:10.1016/j.scs.2014.05.008.

[97] López CSP, Frontini F. Energy Efficiency and Renewable Solar Energy Integration in Heritage Historic Buildings. Energy Procedia 2014;48:1493-502. doi:10.1016/j.egypro.2014.02.169.

[98] Sabrina K. The Identification of the Environment Disposal of the Traditional Algerian Houses. Energy Procedia 2013;42:473-82. doi:10.1016/j.egypro.2013.11.048.

[99] Omar NAM, Syed-Fadzil SF. Assessment of Passive Thermal Performance for a Penang Heritage Shop house. Procedia Eng 2011;20:203-12. doi:10.1016/j.proeng.2011.11.157.

[100] Tassiopoulou T, Grindley PC, Probert SD. Thermal behaviour of an eighteenth-century Athenian dwelling. Appl Energy 1996;53:383-98. doi:10.1016/0306-2619(95)00068-2.

[101] Ascione F, de Rossi F, Vanoli GP. Energy retrofit of historical buildings: theoretical and experimental investigations for the modelling of reliable performance scenarios. Energy Build 2011;43:1925-36. doi:10.1016/j.enbuild.2011.03.040.

[102] Erhorn-Kluttig H, Erhorn H. School of the Future - Towards Zero Emission with High Performance Indoor Environment. Energy Procedia 2014;48:1468-73. doi:10.1016/j.egypro.2014.02.166.

[103] Mørck OC, Paulsen AJ. Energy Saving Technology Screening within the EU-project "School of the Future." Energy Procedia 2014;48:1482-92. doi:10.1016/j.egypro.2014.02.168.

[104] Lagüela S, Martínez J, Armesto J, Arias P. Energy efficiency studies through 3D laser scanning and thermographic technologies. Energy Build 2011;43:1216-21. doi:10.1016/j.enbuild.2010.12.031.

[105] Boarin P. Edilizia Scolastica. Riqualificazione Energetica e Ambientale. Metodologie operative, requisiti, strategie ed esempi per gli interventi sul patrimonio esistente. Monfalcone: EdicomEdozioni; 2010.

[106] Hatamipour MS, Abedi A. Passive cooling systems in buildings: Some useful experiences from ancient architecture for natural cooling in a hot and humid region. Energy Convers Manag 2008;49:2317-23. doi:10.1016/j.enconman.2008.01.018.

[107] Zhai Z (John), Previtali JM. Ancient vernacular architecture: characteristics categorization and energy performance evaluation. Energy Build 2010;42:357-65. doi:10.1016/j.enbuild.2009.10.002.

[108] Sterflinger K, Ettenauer J, Piñar G. Bio-susceptibility of Materials and Thermal Insulation Systems used for Historical Buildings. Energy Procedia 2013;40:499-506. doi:10.1016/j.egypro.2013.08.057.

[109] Abuku M, Janssen H, Roels S. Impact of wind-driven rain on historic brick wall buildings in a moderately cold and humid climate: Numerical analyses of mould growth risk, indoor climate and energy consumption. Energy Build 2009;41:101-10. doi:10.1016/j.enbuild.2008.07.011.

[110] ANSI/ASHRAE. Public Review Draft Energy Guideline for Historical Buildings. Atlanta, GA, USA: 2015.

[111] Krarti M. Evaluation of large scale building energy efficiency retrofit program in Kuwait. Renew Sustain Energy Rev 2015;50:1069-80. doi:10.1016/j.rser.2015.05.063. 
[112] Tadeu S, Rodrigues C, Tadeu A, Freire F, Simões N. Energy retrofit of historic buildings: Environmental assessment of cost-optimal solutions. J Build Eng 2015;4:167-76. doi:10.1016/j.jobe.2015.09.009. 